DE-FG22-96PC96209

\title{
PHASE BEHAVIOR OF LIGHT GASES IN HYDROCARBON AND AQUEOUS SOLVENTS
}

\author{
Report for the Period \\ October 1, 1996 to March 31, 1997
}

\author{
K. A. M. Gasem \\ R. L. Robinson, Jr. \\ (Principal Investigators) \\ N. J. Trivedi \\ W. Gao
}

Oklahoma State University

School of Chemical Engineering

Stillwater, Oklahoma 74078-0537

\section{PREPARED FOR THE UNITITED STATES DEPARTMENT OF ENERGY}




\section{DISCLAIMER}

This report was prepared as an account of work sponsored by an agency of the United States Government. Neither the United States Government nor any agency thereof, nor any of their employees, makes any warranty, express or implied, or assumes any legal liability or responsibility for the accuracy, completeness, or usefulness of any information, apparatus, product, or process disclosed or represents that its use would not infringe privately owned rights. Reference herein to any specific commercial product, process, or service by trade name, trademark, manufacturer, or otherwise does not necessarily constitute or imply its endorsement, recommendation, or favoring by the United States Government or any agency thereof. The views and opinions of authors expressed herein do not necessarily state or reflect those of the United States Government or any agency thereof. 


\title{
PHASE BEHAVIOR OF LIGHT GASES IN HYDROCARBON AND AQUEOUS SOLVENTS
}

\begin{abstract}
Under previous support from the Department of Energy, an experimental facility has been established and operated to measure valuable vapor-liquid equilibrium data for systems of interest in the production and processing of coal fluids. To facilitate the development and testing of models for prediction of the phase behavior for such systems, we have acquired substantial amounts of data on the equilibrium phase compositions for binary mixtures of heavy hydrocarbon solvents with a variety of supercritical solutes, including hydrogen, methane, ethane, carbon monoxide, and carbon dioxide.

The present project focuses on measuring the phase behavior of light gases and water in Fischer-Tropsch (F-T) type solvents at conditions encountered in indirect liquefaction processes and evaluating and developing theoretically-based correlating frameworks to predict the phase behavior of such systems. Specific goals of the proposed work include (a) developing a state-ofthe-art experimental facility to permit highly accurate measurements of equilibrium phase compositions (solubilities) of challenging F-T systems, (b) measuring these properties for systematically-selected binary, ternary and molten $F-T$ wax mixtures to provide critically needed input data for correlation development, (c) developing and testing models suitable for describing the phase behavior of such mixtures, and (d) presenting the modeling results in generalized, practical formats suitable for use in process engineering calculations.

During the present reporting period, our solubility apparatus was refurbished and restored to full service. To test the experimental apparatus and procedures used, measurements were obtained for the solubility of $\mathrm{CO}_{2}$ in benzene at $160{ }^{\circ} \mathrm{F}$. Having confirmed the accuracy of the newly acquired data in comparison with our previous measurements and data reported in the literature for this test system, we have begun to measure the solubility of hydrogen in hexane. The measurements for this system will cover the temperature range from 160 to $280{ }^{\circ} \mathrm{F}$ at pressures to 2,500 psia.

As part of our model evaluation efforts, we examined the predictive abilities of an alternative approach we have proposed for calculating the phase behavior properties of highly non-ideal systems. Using this approach, the liquid phase fugacities generated from an equation of state (EOS) are augmented by a fugacity deviation function correction. The correlative abilities of this approach are compared with those of an EOS equipped with the recently introduced WongSandler (MWS) mixing rules. These two approaches are compared with the current methods for vapor-liquid equilibrium (VLE) calculations, i.e., the $\operatorname{EOS~}(\phi / \phi)$ approach with the van der Waals mixing rules and the split $(\gamma / \phi)$ approach. The evaluations were conducted on a database comprised of non-ideal low pressure binary systems as well as asymmetric high pressure binary systems. These systems are of interest in the coal liquefaction and utilization processes. The Peng-Robinson EOS was selected for the purposes of this evaluation.
\end{abstract}


The proposed method, called the $(\theta / \phi)$ approach, can successfully correlate the binary VLE of highly non-ideal low pressure systems as well as asymmetric high pressure systems. Bubble point pressures were correlated within $2 \%$ for low pressure systems and within $1 \%$ for high pressure systems. The $(\theta / \phi)$ approach shows accuracy comparable to the MWS mixing rules for correlating the binary VLE of the systems considered here. Thus, the use of either approach extends the applicability of equations of state to highly non-ideal systems. However, the proposed amendment to the VLE framework offers a direct means for handling various types of systems and the potential for more useful generalizations and simpler implementation.

A manuscript we have prepared for publication is attached in lieu of detailed technical information. 


\section{TABLE OF CONTENTS}

Section $\quad \underline{\text { Page }}$

Executive Summary 1

$\begin{array}{ll}\text { Manuscript } & 2\end{array}$ 
PROJECT TITLE: "Phase Behavior of Light Gases in Hydrocarbon and Aqueous

PRINCIPAL INVESTIGATORS: K. A. M. Gasem

R. L. Robinson, Jr.

\author{
AFFILIATION: School of Chemical Engineering \\ Oklahoma State University \\ Stillwater, OK 74078 \\ (405) 744-5280
}

PROJECT PERIOD: October 1, 1996 to March 31, 1997

\title{
EXECUTIVE SUMMARY
}

During the present reporting period, our solubility apparatus was refurbished and restored to full service. To test the experimental apparatus and procedures used, measurements were obtained for the solubility of $\mathrm{CO}_{2}$ in benzene at $160^{\circ} \mathrm{F}$. Having confirmed the accuracy of the newly acquired data in comparison with our previous measurements and data reported in the literature for this test system, we have begun to measure the solubility of hydrogen in hexane. The measurements for this system will cover the temperature range from 160 to $280{ }^{\circ} \mathrm{F}$ at pressures to 2,500 psia.

As part of our model evaluation efforts, we examined the predictive abilities of an alternative approach we have proposed for calculating the phase behavior properties of highly non-ideal systems. Using this approach, the liquid phase fugacities generated from an equation of state (EOS) are augmented by a fugacity deviation function correction. The correlative abilities of this approach are compared with those of an EOS equipped with the recently introduced WongSandler (MWS) mixing rules. These two approaches are compared with the current methods for vapor-liquid equilibrium (VLE) calculations, i.e., the EOS $(\phi / \phi)$ approach with the van der Waals mixing rules and the split $(\gamma / \phi)$ approach. The evaluations were conducted on a database comprised of non-ideal low pressure binary systems as well as asymmetric high pressure binary systems. These systems are of interest in the coal liquefaction and utilization processes. The Peng-Robinson EOS was selected for the purposes of this evaluation.

The proposed method, called the $(\theta / \phi)$ approach, can successfully correlate the binary VLE of highly non-ideal low pressure systems as well as asymmetric high pressure systems. Bubble point pressures were correlated within $2 \%$ for low pressure systems and within $1 \%$ for high pressure systems. The $(\theta / \phi)$ approach shows accuracy comparable to the MWS mixing rules for correlating the binary VLE of the systems considered here. Thus, the use of either approach extends the applicability of equations of state to highly non-ideal systems. However, the proposed amendment to the VLE framework offers a direct means for handling various types of systems and the potential for more useful generalizations and simpler implementation. 


\title{
An Amended Framework for Vapor-Liquid Equilibrium Calculations
}

\author{
N. J. Trivedi \\ R. L. Robinson, Jr. \\ K. A. M. Gasem \\ School of Chemical Engineering \\ Oklahoma State University \\ Stillwater, OK 74078
}

Submitted to Fluid Phase Equilibria, December 16, 1996 
Complex mixing rules have been proposed to improve the predictive abilities of equations of state (EOS) for highly non-ideal systems. However, some of these mixing rules are not theoretically sound and are not very widely used. An alternative approach is proposed in this study, wherein the liquid phase fugacities generated from an EOS are augmented by a fugacity deviation function correction. The correlative abilities of this approach are compared with those of an EOS equipped with the recently introduced Wong-Sandler (MWS) mixing rules. These two approaches are compared with the current methods for vapor-liquid equilibrium (VLE) calculations, i.e., the EOS $(\phi / \phi)$ approach with the van der Waals mixing rules and the split $(\gamma / \phi)$ approach. The evaluations were conducted on a database comprised of non-ideal low pressure binary systems as well as asymmetric high pressure binary systems. The Peng-Robinson EOS was selected for the purposes of this evaluation.

The proposed method, called the $(\theta / \phi)$ approach, can successfully correlate the binary VLE of highly non-ideal low pressure systems as well as asymmetric high pressure systems. Bubble point pressures were correlated within $2 \%$ for low pressure systems and within $1 \%$ for high pressure systems. The $(\theta / \phi)$ approach shows accuracy comparable to the MWS mixing rules for correlating the binary VLE of the systems considered here. Thus, the use of either approach extends the applicability of equations of state to highly non-ideal systems. However, the proposed amendment to the VLE framework offers a direct means for handling various types of systems and the potential for more useful generalizations and simpler implementation. 


\section{INTRODUCTION}

The accurate prediction of thermodynamic properties of mixtures is essential in nearly every area of chemical engineering for process design and optimization calculations. The most convenient tool for the description of equilibrium phase behavior has long been recognized to be analytic equations of state (Prausnitz, 1977). Historically, the most commonly used equations of state (EOS) are the cubic van der Waals type equations such as the Peng-Robinson (Peng and Robinson, 1976) and the Soave-Redlich-Kwong (Soave, 1972) EOS. Perhaps, the greatest utility of cubic EOS is for phase equilibrium calculations involving mixtures (see, e.g., Prausnitz et al., 1986; Walas, 1985; Anderko, 1990). The assumption inherent in such calculations is that the same EOS can be used both for pure fluids and mixtures, once a satisfactory procedure for obtaining the mixture parameters from pure fluid parameters is identified. This is accomplished using mixing rules, the most common being the van der Waals one-fluid mixing rules equipped with combining rules containing adjustable parameters. However, the van der Waals mixing rules generally cannot describe the behavior of highly non-ideal mixtures containing polar or associating molecules. For such mixtures, the alternative approach has been the use of activity coefficient models for the condensed phase and an EOS for the vapor phase (Prausnitz, 1977). However, this approach, the spli $(\gamma / \phi)$ approach also has its drawbacks, the most prominent of which is the need for the use of hypothetical standard states.

To avoid the use of activity coefficient models and to improve the predictive abilities of the conventional EOS, various complex mixing rules have been proposed. However, most of these mixing rules also have fundamental drawbacks and are not very widely used (Sandler et al., 1994). Recently, a new set of mixing rules, which are theoretically sound were introduced by 
Wong and Sandler (1992). Orbey and Sandler (1995) proposed a reformulation of these mixing rules. The predictive abilities of these modified Wong-Sandler (MWS) mixing rules are not very well known, and the need exists for evaluating their ability to describe the behavior of complex mixtures.

An alternative approach has been suggested to address some of the limitations of the current VLE framework (Gasem, 1989). The basic premise of this new method is to use a fugacity deviation function to augment the fugacity calculated from an EOS. As mentioned

previously, an EOS with the conventional mixing rules cannot represent the behavior of highly non-ideal solutions. The hypothesis is that a systematic correction to the fugacities calculated from the EOS may alleviate this problem without altering the EOS mixing rules.

The main goal of this work is to assess the efficacy of this new VLE framework. The specific objectives of this study are to

1. Evaluate the effect of a fugacity deviation function correction on the phase behavior predictive abilities of an EOS.

2. Evaluate the comparable phase behavior predictive abilities of the EOS using the MWS mixing rules.

3. Compare the above with the conventional methods for calculating phase equilibrium properties, i.e., the EOS $(\phi / \phi)$ approach with the van der Waals mixing rules and the split $(\gamma / \phi)$ approach.

\section{PROPOSED METHOD}

The EOS $(\phi / \phi)$ approach has inherent limitations in that it cannot model phase equilibrium for systems which exhibit appreciable solution non-ideality (see, e.g., Prausnitz, 1977; Sandler et 
al., 1994). The main problem with this approach is the accurate representation of liquid phase behavior. An attempt was made to alleviate this drawback by correcting the EOS liquid phase fugacities by using a deviation function (Gasem, 1989). The fugacity deviation function, say $\hat{\theta}_{\mathrm{i}}$, can be defined by

$$
\hat{\theta}_{i}=\frac{\hat{\mathrm{f}}_{\mathrm{i}}}{\hat{\mathrm{f}}_{\mathrm{i}}^{\text {eos }}}
$$

where, $\hat{\mathrm{f}}_{\mathrm{i}}$ is the actual fugacity of the component and $\hat{\mathrm{f}}_{\mathrm{i}}^{\mathrm{eos}}$ is the fugacity calculated by the EOS used to model the solution behavior. There are two important limits at which the value of $\hat{\theta}_{\mathrm{i}}$ needs to be defined. These are

$$
\begin{aligned}
& \hat{\theta}_{\mathrm{i}} \rightarrow 1 \quad \text { as } \quad \mathrm{z}_{\mathrm{i}} \rightarrow 1 \\
& \hat{\theta}_{\mathrm{i}} \rightarrow 1 \text { as } \mathrm{p} \rightarrow 0
\end{aligned}
$$

The first limit makes the fugacities calculated by the EOS applicable at the pure limits. The second limit ensures that the fugacity of a component approaches the partial pressure at the limit of zero pressure. Other limiting conditions, however, may be used to define the pure component limits; for example, a volume translation could be implemented to improve the pure fluid property predictions.

Accordingly, the chemical potential of a component in a phase can be expressed by

$$
\mu_{\mathrm{i}}=\mu_{\mathrm{i}}^{\mathrm{o}}+\mathrm{RT} \ln \hat{\theta}_{\mathrm{i}} \hat{\mathrm{f}}_{\mathrm{i}}^{\mathrm{eos}}
$$

where $\mu_{\mathrm{i}}^{\circ}$ is the pure component chemical potential at the system temperature and unit fugacity. The total Gibbs free energy of a phase is defined by (Denbigh, 1981)

$$
\mathrm{G}=\sum \mathrm{n}_{\mathrm{i}} \mu_{\mathrm{i}}
$$

Substituting the value of the chemical potential from Equation (3) 


$$
\mathrm{G}=\sum \mathrm{n}_{\mathrm{i}} \mu_{\mathrm{i}}^{\mathrm{o}}+\mathrm{RT} \sum \mathrm{n}_{\mathrm{i}} \ln \hat{\mathrm{f}}_{\mathrm{i}}^{\mathrm{eos}}+\mathrm{RT} \sum \mathrm{n}_{\mathrm{i}} \ln \hat{\theta}_{\mathrm{i}}
$$

If the solution behavior is modeled solely by the EOS, the last term would be zero. Therefore, the excess free energy (with reference to the particular EOS) is

$$
\mathrm{G}_{\mathrm{eos}}^{\mathrm{E}}=\mathrm{RT} \sum \mathrm{n}_{\mathrm{i}} \ln \hat{\theta}_{\mathrm{i}}
$$

If we differentiate the above expression at constant temperature and pressure

$$
\mathrm{dG}_{\text {eos }}^{\mathrm{E}}=\mathrm{RT} \sum \mathrm{n}_{\mathrm{i}} \mathrm{d} \ln \hat{\theta}_{\mathrm{i}}+\mathrm{RT} \sum \ln \hat{\theta}_{\mathrm{i}} \mathrm{d} \mathrm{n}_{\mathrm{i}}
$$

The Gibbs-Duhem equation for a given phase is (Denbigh, 1981)

$$
-\mathrm{SdT}+\mathrm{Vdp}-\sum \mathrm{n}_{\mathrm{i}} \mathrm{d} \mu_{\mathrm{i}}=0
$$

At a constant temperature and pressure, substituting for the chemical potential from Equation (3), the above equation can be written as

$$
\sum n_{i} d \ln \hat{\theta}_{i}+\sum n_{i} d \ln \hat{f}_{i}^{e o s}=0
$$

The second term on the left hand side of the above equation has to be equal to zero to satisfy the Gibbs-Duhem equation for the conventional EOS approach. Thus, the first term is also equal to zero. It follows from the preceding discussion, that at a constant temperature, pressure and mole numbers of the other components of the mixture $\left(\mathrm{n}_{\mathrm{j}}\right)$, Equation (7) leads to

$$
\left(\frac{\partial \mathrm{G}_{\mathrm{eos}}^{\mathrm{E}}}{\partial \mathrm{n}_{\mathrm{i}}}\right)_{\mathrm{T}, \mathrm{P}, \mathrm{n}_{\mathrm{j}}}=R T \ln \hat{\theta}_{\mathrm{i}}
$$

Thus, if an expression can be obtained for the excess Gibbs energy, $G_{\text {eos }}^{\mathrm{E}}$, the coefficients $\hat{\theta}_{\mathrm{i}}$ for the individual species can be determined by differentiating $G_{e o s}^{E}$ with respect to $n_{i}$. The fugacity deviation function $\hat{\theta}_{i}$ can also be calculated from experimental partial molar volume data by the following equation 


$$
\ln \hat{\theta}_{i}=\frac{1}{R T} \int_{0}^{p}\left(\widetilde{v}_{i}-\widetilde{v}_{i}^{\text {eos }}\right) d p
$$

where $\widetilde{v}_{i}$ is the actual partial molar volume and $\widetilde{v}_{i}^{\text {eos }}$ is the partial molar volume calculated by the EOS. For convenience, the fugacity deviation function $\theta$ can also be correlated empirically by any of the conventional activity coefficient models (or any correlation that obeys the Gibbs-Duhem relation). However, such a strategy is not optimum for deriving the full benefit of this approach.

This approach may be called the $(\theta / \phi)$ approach to distinguish it from the $(\phi / \phi)$ approach. In terms of deviation functions, this method essentially involves selecting an EOS as the reference model for evaluating mixture properties. Figure 1 compares the deviation functions $\theta$ (deviation from an EOS) and $\gamma$ (deviation from an ideal solution) obtained for the acetone + water system at 373.2 K. This figure is shown for illustrative purposes only and no inference regarding the relative magnitudes of the deviation functions can be drawn from it. However, one should normally expect the deviation function $\theta$ to be smaller than $\gamma$, since an EOS is generally a better reference model than an ideal solution. Also, $\theta$ may at times show maxima or minima, when plotted as a function of composition, and a model for $\theta$ should be able to handle such behavior.

\section{MODEL EVALUATIONS}

Four different methods were evaluated in this study for correlating binary vapor-liquid equilibrium (VLE) of the systems considered. The four VLE methods are listed in Table 1 as specific case studies. In Case 1, the Peng-Robinson EOS is used with the traditional van der Waals mixing rules for the vapor phase (with no interaction parameters) and the NRTL model (Renon and Prausnitz, 1965) for the liquid phase. The Peng-Robinson EOS (Peng and Robinson, 1976) is given as follows 


$$
p=\frac{R T}{v-b}-\frac{a(T)}{v(v+b)+b(v-b)}
$$

where

$$
\begin{aligned}
& \mathrm{a}(\mathrm{T})=\mathrm{a}_{\mathrm{c}} \alpha(\mathrm{T}) \\
& \mathrm{b}=0.07780 \mathrm{RT}_{\mathrm{c}} / \mathrm{p}_{\mathrm{c}}
\end{aligned}
$$

and

$$
\begin{aligned}
& \mathrm{a}_{\mathrm{c}}=0.45724 \mathrm{R}^{2} \mathrm{~T}_{\mathrm{c}}^{2} / \mathrm{p}_{\mathrm{c}} \\
& \alpha(\mathrm{T})^{1 / 2}=1+\mathrm{K}\left(1-\mathrm{T}_{\mathrm{r}}^{1 / 2}\right) \\
& \mathrm{K}=0.37464+1.54226 \omega-0.26992 \omega^{2}
\end{aligned}
$$

The equations for the van der Waals mixing rules are shown below

$$
\begin{aligned}
& \mathrm{a}=\sum \sum \mathrm{z}_{\mathrm{i}} \mathrm{z}_{\mathrm{j}} \mathrm{a}_{\mathrm{ij}} \\
& \mathrm{b}=\sum \sum \mathrm{z}_{\mathrm{i}} \mathrm{z}_{\mathrm{j}} \mathrm{b}_{\mathrm{ij}}
\end{aligned}
$$

In addition, combining rules are needed for the parameters $a_{i j}$ and $b_{i j}$. The usual combining rules are

$$
\begin{aligned}
& \mathrm{a}_{\mathrm{ij}}=\sqrt{\mathrm{a}_{\mathrm{ii}} \mathrm{a}_{\mathrm{jj}}}\left(1-\mathrm{C}_{\mathrm{ij}}\right) \\
& \mathrm{b}_{\mathrm{ij}}=\frac{1}{2}\left(\mathrm{~b}_{\mathrm{ii}}+\mathrm{b}_{\mathrm{ij}}\right)\left(1+\mathrm{D}_{\mathrm{ij}}\right)
\end{aligned}
$$

where $C_{i j}$ and $D_{i j}$ are empirical "binary interaction parameters" obtained by fitting EOS predictions to experimental data.

The NRTL model can be written as

$$
\frac{\overline{\mathrm{G}}^{\mathrm{E}}}{\mathrm{RT}}=\sum_{\mathrm{i}} \mathrm{z}_{\mathrm{i}}\left[\frac{\sum_{\mathrm{j}} \mathrm{z}_{\mathrm{j}} \mathrm{G}_{\mathrm{ji}} \tau_{\mathrm{ji}}}{\sum_{\mathrm{k}} \mathrm{z}_{\mathrm{k}} \mathrm{G}_{\mathrm{ki}}}\right]
$$




$$
\mathrm{G}_{\mathrm{ji}}=\exp \left(-\alpha_{\mathrm{ij}} \tau_{\mathrm{ji}}\right)
$$

where $\overline{\mathrm{G}}^{\mathrm{E}}$ is the molar excess Gibbs free energy. The expression for the activity coefficient is

$$
\ln \gamma_{\mathrm{i}}=\frac{\sum_{\mathrm{j}} \mathrm{z}_{\mathrm{j}} \tau_{\mathrm{ji}} \mathrm{G}_{\mathrm{ji}}}{\sum_{\mathrm{k}} \mathrm{z}_{\mathrm{k}} \mathrm{G}_{\mathrm{ki}}}+\sum_{\mathrm{j}} \frac{\mathrm{z}_{\mathrm{j}} \mathrm{G}_{\mathrm{ij}}}{\sum_{\mathrm{k}} \mathrm{z}_{\mathrm{k}} \mathrm{G}_{\mathrm{kj}}}\left(\tau_{\mathrm{ij}}-\frac{\sum_{\mathrm{l}} \mathrm{z}_{\mathrm{l}} \tau_{\mathrm{lj}} \mathrm{G}_{\mathrm{lj}}}{\sum_{\mathrm{k}} \mathrm{z}_{\mathrm{k}} \mathrm{G}_{\mathrm{kj}}}\right)
$$

In this case, the parameters to be regressed are the model parameters $\tau_{12}, \tau_{21}$ and $\alpha_{12}$. This is the split $(\gamma / \phi)$ approach. Case 1 has been used for non-ideal low pressure systems only, as excess free energy models are well suited for such systems.

In Case 2, the Peng-Robinson EOS, equipped with the van der Waals mixing rules employing two interaction parameters $\left(\mathrm{C}_{\mathrm{ij}}\right.$ and $\left.\mathrm{D}_{\mathrm{ij}}\right)$, is used. The parameters to be regressed are the interaction parameters $\mathrm{C}_{\mathrm{ij}}$ and $\mathrm{D}_{\mathrm{ij}}$. Case 2 has been used for high pressure systems only, as equations of state with the van der Waals mixing rules generally cannot handle the behavior of highly non-ideal systems (Sandler et al., 1994).

In Case 3, the Peng-Robinson EOS equipped with the MWS mixing rules is used. The equations for the MWS mixing rules are shown below

$$
\begin{aligned}
& \mathrm{b}=\frac{\sum \sum \mathrm{z}_{\mathrm{i}} \mathrm{z}_{\mathrm{j}}\left(\mathrm{b}-\frac{\mathrm{a}}{\mathrm{RT}}\right)_{\mathrm{ij}}}{1-\frac{\overline{\mathrm{A}}^{\mathrm{E}}}{\sigma \mathrm{RT}}-\sum \mathrm{z}_{\mathrm{i}} \frac{\mathrm{a}_{\mathrm{i}}}{\mathrm{RTb_{i }}}} \\
& \frac{\mathrm{a}}{\mathrm{b}}=\sum \mathrm{z}_{\mathrm{i}} \frac{\mathrm{a}_{\mathrm{i}}}{\mathrm{b}_{\mathrm{i}}}+\frac{\overline{\mathrm{A}}^{\mathrm{E}}}{\sigma}
\end{aligned}
$$

In Equations (25) and (26), $\overline{\mathrm{A}}^{\mathrm{E}}$ is the molar excess Helmholtz free energy and $\sigma$ is a numerical constant, which depends on the EOS being used (e.g., $\sigma=-0.62323$ for the Peng-Robinson EOS). The combining rule for the cross second virial coefficient in Equation (25) is 


$$
\left(b-\frac{a}{R T}\right)_{i j}=\frac{b_{i}+b_{j}}{2}-\frac{\sqrt{a_{i} a_{j}}}{R T}\left(1-C_{i j}\right)
$$

The Gibbs excess model used with these mixing rules was a modified NRTL model (Huron and Vidal, 1979). The equations for the modified NRTL model are the same as Equations (22) and (24). Only Equation (23) is changed to

$$
\mathrm{G}_{\mathrm{ji}}=\mathrm{b}_{\mathrm{j}} \exp \left(-\alpha_{\mathrm{ij}} \tau_{\mathrm{ji}}\right)
$$

where $b_{j}$ is the EOS covolume parameter (Equation 12). In this case, the parameters to be regressed are the interaction parameter $C_{\mathrm{ij}}$ and the excess model parameters $\tau_{12}, \tau_{21}$ and $\alpha_{12}$. Cases 2 and 3 both represent variations of the $(\phi / \phi)$ approach. However, in this study, a reference to the $(\phi / \phi)$ approach, without any mention of the mixing rules used, should be understood as a reference to Case 2, as it is the more commonly used approach.

In Case 4, the Peng-Robinson EOS is used with the van der Waals mixing rules employing one interaction parameter $\left(\mathrm{C}_{\mathrm{ij}}\right)$, and a fugacity deviation function correction is applied to the calculated liquid fugacity. The fugacity deviation function used for this case was the RedlichKister model (Walas, 1985)

$$
\begin{aligned}
& \ln \hat{\theta}_{1}=z_{2}^{2}\left[B+C\left(3 z_{1}-z_{2}\right)+D\left(z_{1}-z_{2}\right)\left(5 z_{1}-z_{2}\right)\right] \\
& \ln \hat{\theta}_{2}=z_{1}^{2}\left[B+C\left(z_{1}-3 z_{2}\right)+D\left(z_{1}-z_{2}\right)\left(z_{1}-5 z_{2}\right)\right]
\end{aligned}
$$

The excess Gibbs free energy model from which these equations are derived is

$$
\frac{\overline{\mathrm{G}}^{\mathrm{E}}}{\mathrm{RT}}=\mathrm{z}_{1} \mathrm{z}_{2}\left[\mathrm{~B}+\mathrm{C}\left(\mathrm{z}_{1}-\mathrm{z}_{2}\right)+\mathrm{D}\left(\mathrm{z}_{1}-\mathrm{z}_{2}\right)^{2}\right]
$$

In this case, the parameters to be regressed are the interaction parameter $\mathrm{C}_{\mathrm{ij}}$ and the model parameters B, C and D. This is the proposed $(\theta / \phi)$ approach. The Redlich-Kister model was 
selected, in preference to some other models, after some preliminary trials. However, it was not selected for theoretical reasons but as a flexible model to explore the merits of this method. Eventually, one should seek a more precise excess model to account for deviations in phase behavior beyond the reference EOS.

The model evaluations were performed using the GEOS (Generalized EOS )software developed at Oklahoma State University (Gasem, 1988-1996). Model parameters were regressed to minimize deviations in bubble point pressure predictions only. The objective function used for minimization was

$$
\mathrm{SS}=\sum_{\mathrm{i}=1}^{\mathrm{npts}}\left(\frac{\mathrm{p}_{\mathrm{i}}^{\text {exp }}-\mathrm{p}_{\mathrm{i}}^{\text {cal }}}{p_{\mathrm{i}}^{\text {exp }}}\right)^{2}
$$

where, the superscripts exp and cal refer to experimental and calculated values, respectively. The summation is over the total number of points (npts) in the data set. The quality of fit was assessed by calculating the root-mean-squared error (RMSE), percentage average absolute deviation (\%AAD) and bias (BIAS) for each data set. Definitions of these statistics are given in the Nomenclature. 


\section{DATABASE USED}

The four methods discussed in the previous section were evaluated using a database comprised of non-ideal systems at low pressures as well as systems at high pressures. Only binary VLE data were used in this study. At low pressures, a majority of the systems considered involved water with different compounds. The compounds were chosen to represent several classes of chemicals (alcohols, acids, aldehydes, ethers, ketones, etc.). Some other systems exhibiting near-ideal behavior were also considered. The data for most low pressure systems were taken from the DECHEMA Chemistry Data Series (DECHEMA, 1977). At high pressures, the database consisted of binary mixtures of different hydrocarbons with ethane, carbon dioxide, nitrogen and hydrogen. The hydrocarbons were chosen to represent several classes of compounds (n-alkanes, naphthenes and aromatics). The data for these systems were taken from an extensive database previously compiled at Oklahoma State University (Raghunathan, 1996). The sources and range of data used are shown in Tables 2-6. Table 7 lists the physical constants $\left(T_{c}, p_{c}\right.$ and $\left.\omega\right)$ used in the evaluation and their sources. Physical constants and the vapor pressure model for compounds involved in the systems at low pressure have been taken from Aspen Plus ${ }^{\mathrm{TM}}$ (AspenTech, 1995).

\section{RESULTS}

The overall results for the different types of systems studied here are summarized in Table 8. For low pressure systems, Case 1 shows the best results of the three cases studied $(\mathrm{RMSE}=$ 0.007 bar, $\% \mathrm{AAD}=1.02$ ). As mentioned previously, Case 2 was not studied for non-ideal low pressure systems, as EOS with the van der Waals mixing rules often cannot handle the behavior of 
these systems. The overall results for these systems are essentially similar for Case 3 (RMSE = 0.009 bar, \%AAD = 1.84) and Case $4(\mathrm{RMSE}=0.009$ bar, \%AAD $=1.58)$ for bubble point pressure predictions. VLE plots for a few sample systems, comparing the different methods, are also shown in Figures 2-4. For all the figures, the continuous lines represent model predictions and the symbols represent experimental data, with the filled symbols representing the liquid phase. The figures indicate that good representation of the phase behavior is obtained in Cases 3 and 4 . In addition, dramatic improvement in the quality of the fit near the pure limits (comparable to Case 1) is realized when the pure component vapor pressures are accurately reproduced, as shown by Figures 2 and 4.

As mentioned previously, Case 1 was not studied for high pressure systems as activity coefficient models are not well suited for such systems. The results for the binary ethane + hydrocarbon systems indicate that all three models show similar results. Case 2 (RMSE $=0.43$ bar, \%AAD $=1.17)$ and Case $3(\mathrm{RMSE}=0.42$ bar, \%AAD $=0.88)$ do slightly worse than Case 4 $(\mathrm{RMSE}=0.19$ bar, \%AAD $=0.51)$. The results for the binary carbon dioxide + hydrocarbon systems show the same trend. Case $4(\mathrm{RMSE}=0.28$ bar, \%AAD $=0.58)$ does marginally better than Case $2(\mathrm{RMSE}=0.78$ bar, \%AAD $=0.96)$ and Case $3(\mathrm{RMSE}=0.36$ bar, \%AAD $=0.78)$. The results for the binary nitrogen + hydrocarbon systems indicate that Case 2 (RMSE $=2.24$ bar, $\% \mathrm{AAD}=1.91)$, Case $3(\mathrm{RMSE}=2.27$ bar, \%AAD $=1.57)$ and Case $4(\mathrm{RMSE}=2.08$ bar, $\% \mathrm{AAD}=1.54)$ show essentially the same results, albeit, on a relative (\%AAD) basis, Case 2 does slightly worse than Cases 3 and 4. However, the model parameters for Case 3 are not stable for some systems, and difficulties in convergence were experienced.

Typically, systems for which convergence was difficult resulted in large values for the parameter $\tau_{12}$. The nitrogen $+n$-decane system offers an example of the convergence problem. In 
this case, one data point at $410.9 \mathrm{~K}$ did not converge. Thus, the parameters were optimized after discarding that particular point, and the isotherm was not included in the overall analysis. The results for the binary hydrogen + hydrocarbon systems indicate that Case 2 (RMSE $=1.81$ bar, $\% \mathrm{AAD}=1.02)$ and Case $3(\mathrm{RMSE}=2.08$ bar, \%AAD $=1.13)$ show essentially similar results. Case $4(\mathrm{RMSE}=0.85$ bar, \%AAD $=0.56)$ does marginally better than Cases 2 and 3. However, Case 3 again showed convergence problems. The hydrogen $+\mathrm{n}$-hexadecane system at $622.9 \mathrm{~K}$ and the hydrogen + benzene system at $423.2 \mathrm{~K}$ each had one non-convergent point. Again, the parameters were optimized after discarding the non-convergent points and the particular isotherms were not included in the overall analysis.

The results for the non-ideal low pressure systems show that the $(\gamma / \phi)$ approach (Case 1) does better than Cases 3 and 4. However, this should be expected since the $(\gamma / \phi)$ approach uses a vapor pressure model to obtain accurate pure component vapor pressures. The calculations using the MWS mixing rules (Case 3) and the $(\theta / \phi)$ approach (Case 4) were performed without any tuning of pure fluid parameters to obtain accurate pure component vapor pressures. Accurate representation of pure component vapor pressures is one of the important factors affecting phase equilibrium predictions. Figures 2(B) and 4(B), representing VLE for the 2-propanol + water system and the acetonitrile + tert-butanol system respectively, are excellent examples which illustrate this assertion. In these figures, the acentric factors of the individual components were tuned to generate accurate pure component vapor pressures for Cases 3 and 4 . A comparison of Figures 2(B) and 4(B) with Figures 2(A) and 4(A) respectively, shows improved accuracy for Cases 3 and 4, which may be ascribed to good pure component parameters.

The overall results for the asymmetric high pressure systems considered here indicate that both Cases 3 and 4 show better results than Case 2. However, this should be expected of four- 
parameter models like the ones used in this study compared to an equation of state with only two interaction parameters. However, the point in question is not the correlative ability of models for specific systems, but developing a framework which can be used for a wider variety of systems than is currently possible. To this extent, both the MWS mixing rules and the $(\theta / \phi)$ approach proved successful. The use of either approach also eliminates the need for reference states for calculating fugacities, which is a major drawback of the $(\gamma / \phi)$ method.

\section{The $(\theta / \phi)$ Approach Model Parameter Temperature Dependence}

The analysis for the systems studied here was done on an isotherm-by-isotherm basis, i.e., model parameters were regressed for individual isotherms of each system. This represents the ultimate ability of any model to correlate phase behavior. However, in practice, a single set of parameters is generally used to represent the phase behavior of a system over a range of temperature. For this purpose, the temperature dependence of the model parameters for the $(\theta / \phi)$ approach was investigated for certain sample systems.

The temperature dependence was investigated using five systems. The systems chosen were acetone + water, ethane $+n$-octacosane, carbon dioxide $+n$-decane, nitrogen $+n-$ hexadecane and hydrogen + toluene. The temperature dependence was investigated for three different cases. Case 4, as discussed in the previous section, is the correlation of the vapor-liquid equilibrium of the system with individual parameters for each temperature. Case $4 \mathrm{a}$ is the prediction of vapor-liquid equilibrium of the system at all temperatures using parameters based on a single (lowest) temperature. Case $4 \mathrm{~b}$ is the correlation of vapor-liquid equilibrium of the system at all temperatures using a set of regressed parameters determined to fit the entire data set. The results for the representation of bubble point pressures for the three cases are shown in Table 9. 
Sample VLE curves are also shown in Figures 5-8.

The results for the acetone + water system are shown on two separate figures (Figures 5 and 6) due to a different scale being required for the highest temperature. Case 4, as expected, shows the best results for all the systems considered here. Case $4 \mathrm{a}$ is in good agreement with the experimental data at $323.2 \mathrm{~K}$, but at $373.2 \mathrm{~K}$, it predicts slightly different bubble point pressures. The same observation applies to results for Case $4 b$, which shows a qualitatively better fit than Case 4a. Both cases predict vapor compositions for acetone which are slightly high. The results for the ethane $+n$-octacosane system indicate that all three cases yield very similar results. For the carbon dioxide $+\mathrm{n}$-decane system, Case 4 a predicts slightly higher bubble point pressures for the $410.9 \mathrm{~K}$ and $510.9 \mathrm{~K}$ isotherms. Case $4 \mathrm{~b}$, however shows excellent agreement with the data for all isotherms. The results for the nitrogen + hexadecane system, shown in Figure 7, indicate excellent results for both Case $4 \mathrm{a}$ and $4 \mathrm{~b}$. The results for the hydrogen + toluene system are shown in Figure 8. In this case, the results for Cases $4 \mathrm{a}$ and $4 \mathrm{~b}$ are the same, i.e., the parameters for the lowest isotherm $(461.9 \mathrm{~K})$ gave a fit comparable to that using parameters regressed for the complete data set. Thus, only a single curve has been drawn for both cases. There is good qualitative agreement with the data for both isotherms, but at higher pressures, the predicted bubble point pressures are slightly lower.

In general, the results for Case $4 \mathrm{a}$ indicate that the model parameters, though not temperature independent, show good qualitative fits for temperatures higher than the temperature at which they were obtained. Case $4 \mathrm{~b}$ shows slightly better results, which indicates that a single set of parameters could be used over a range of temperature to give reasonably accurate predictions. Table 10 compares the results for Case $4 \mathrm{~b}$ with the results obtained using the conventional approaches (Cases 1 and 2 described in the previous section) on a system-by-system 
basis, i.e., one set of parameters for a system. The comparison shows that the $(\theta / \phi)$ approach does marginally better than the $(\phi / \phi)$ approach (Case 1) for systems at high pressures and does marginally worse than the $(\gamma / \phi)$ approach (Case 2) for the acetone + water system. The overall results indicate that Case 4 is required for high accuracies using the $(\theta / \phi)$ approach.

\section{DISCUSSION}

Parity in the correlative abilities of the proposed $(\theta / \phi)$ approach and the MWS mixing rules is a positive and significant outcome. The results indicate that amending the VLE framework offers good correlative capabilities without resorting to complexity in the EOS mixing rules. Moreover, the present study demonstrates the efficacy of perturbation of auxiliary equilibrium functions (such as fugacity), as opposed to potential energy functions (e.g., Helmholtz energy) or a partition function at the molecular level.

The current excess energy mixing rules are limited to use with cubic equations of state only, whereas the $(\theta / \phi)$ approach can be used with any equation of state. Also, as stated previously, these excess mixing rules (such as MWS) are limited to certain excess energy models and parameter values if they are to be used with the van der Waals mixing rules in multicomponent systems. However, there is no such limitation on the $(\theta / \phi)$ approach, as its function is to model deviations from any equation of state with any set of mixing rules. The $(\theta / \phi)$ approach, being an amendment to the VLE framework, offers a direct means of extending the applicability of equations of state to highly non-ideal systems, has potential for more useful generalizations, and reduces the need for developing complex mixing rules like the MWS rules. Moreover, the $(\theta / \phi)$ approach is very easy to implement within existing computational algorithms for any equation of state. 
This preliminary study indicates that the proposed $(\theta / \phi)$ approach addresses some of the limitations of the current VLE framework and offers a unified method for handling diversity in phase behavior. Nevertheless, further studies are required to address several outstanding issues. As was stated earlier, the Redlich-Kister excess Gibbs energy model was selected, after some preliminary trials, as the fugacity deviation function model. The selection was based mostly on empirical consideration and for the purpose of demonstrating the viability of the proposed method. To fully benefit from the $(\theta / \phi)$ approach, efforts should be directed toward developing a more rational excess model to account for deviations in phase behavior beyond the reference EOS.

In addition to rigorous derivation of the fugacity deviation function $\theta$, the choice of reference EOS will also have a significant influence on the equality of the equilibrium predictions. In this study, we have used the Peng-Robinson EOS with a binary interaction parameter. Ideally, one should use theoretically-based EOS founded on clearly stated molecular attributes; thus, the observed phase behavior is correlated with the structure of the molecules involved. In such a case, the deviation function $\theta$ would be an amendment reflective of the molecular complexity. For example, one could use an EOS capable of representing normal fluids as a reference model and the deviation function $\theta$ to account for polarity or molecular size disparity.

The model evaluations in this study were limited to binary systems only. However, the $(\theta / \phi)$ approach may be extended to systems containing three or more components. For extension to multicomponent systems (ternary or higher), excess free energy models structurally akin to the NRTL or Wilson model are recommended for $\theta$. These models can be applied to multicomponent systems with binary parameters, whereas models like the Redlich-Kister model need ternary or higher parameters for such systems. 


\section{CONCLUSIONS AND RECOMMENDATIONS}

\section{Conclusions}

1. The proposed method, called the $(\theta / \phi)$ approach, can successfully correlate the binary VLE of highly non-ideal low pressure systems as well as asymmetric high pressure systems. Bubble point pressures were correlated within $2 \%$ for low pressure systems and within $1 \%$ for high pressure systems.

2. The $(\theta / \phi)$ approach shows accuracy comparable to the MWS mixing rules for correlating the binary VLE of the systems considered here. Thus, the use of either approach extends the applicability of equations of state to highly non-ideal systems. However, the proposed amendment to the VLE framework offers a direct means for handling various types of systems and the potential for more useful generalizations and simpler implementation.

3. The temperature dependence of the model parameters for the $(\theta / \phi)$ approach was investigated using a number of sample systems. The results show that good qualitative fits are obtained using a single set of parameters over a range of temperature. However, a set of parameters for each temperature is recommended for high precision.

\section{Recommendations}

1. The model used in this work for the fugacity deviation function was selected, based on limited preliminary trials. Effective modeling of both the reference EOS and the fugacity deviation function, using the current advancements in molecular thermodynamics, should be attempted to develop a theoretically sound model. This, in turn, might lead to generalizability of model parameters, if not reasonable a priori prediction of phase behavior for systems for which experimental data are not available. 
2. The applicability of the $(\theta / \phi)$ approach to multicomponent systems (ternary or higher) should be investigated.

3. The generalizability of the deviation function model parameters should be addressed. 


\section{LITERATURE CITED}

Anderko, A., 1990. Equation-of-state methods for the modelling of phase equilibria. Fluid Phase Equilibria, 61: 145.

AspenTech, 1995. Aspen Plus, Release 9.1-3. Cambridge, Massachusetts.

Azarnoosh, A. and McKetta, J. J., 1963. Nitrogen-n-decane system in the two-phase region. J. Chem. Eng. Data, 8: 494.

DECHEMA Chemistry Data Series, 1977 and thereafter. DECHEMA, Frankfurt.

Denbigh, K., 1981. Principles of Chemical Equilibrium, $4^{\text {th }}$ Edition, Cambridge University Press, Cambridge.

Gasem, K. A. M., 1988-1996. GEOS Software. Oklahoma State University, Stillwater, Oklahoma.

Gasem, K. A. M., 1989. Personal communication.

Huron, M.-J. and Vidal, J., 1979. New mixing rules in simple equations of state for representing vapor-liquid equilibria of strongly nonideal mixtures. Fluid Phase Equilibria, 3: 255.

Orbey, H. and Sandler, S. I., 1995. Reformulation of Wong-Sandler mixing rule for cubic equations of state. AIChE J., 41 (3): 683.

Peng, D. Y. and Robinson, D. B., 1976. A new two-constant equation of state. Ind. Eng. Chem. Fund., 15: 59.

Prausnitz, J. M., 1977. State-of-the-art review of phase equilibria. In: Storvick, T.S. and Sandler, S. I. (Eds.), Phase Equilibria and Fluid Properties in the Chemical Industry, American Chemical Society, Washington, D. C.: 11.

Prausnitz, J. M., Lichtenthaler, R. N. and Azevedo, E. G., 1986. Molecular Thermodynamics of Fluid-Phase Equilibria, $2^{\text {nd }}$ Edition, Prentice-Hall, Eaglewood Cliffs, New Jersey.

Raghunathan, S., 1996. EOS Model Evaluation for Asymmetric Mixtures and a Graphical Interface Implementation. M.S. Thesis, Oklahoma State University, Stillwater, Oklahoma.

Renon, H. and Prausnitz, J. M., 1965. Local compositions in thermodynamic excess functions for liquid mixtures. AIChe J., 14: 135.

Sandler, S. I., Orbey, H. and Lee, B. I., 1994. Equations of state. In: Sandler, S. I. (Eds.), 
Models for Thermodynamic and Phase Equilibria Calculations, Marcel Dekker, New York: 87.

Soave, G., 1972. Equilibrium constants from a modified Redlich-Kwong equation of state. Chem. Eng. Sci., 27: 1197.

Walas, S., 1985. Phase Equilibria in Chemical Engineering. Butterworth Publishers, Stoneham, Massachusetts

Wong, D. S. H. and Sandler, S. I., 1992. A theoretically correct mixing rule for cubic equations of state. AIChE J., 38: 671. 


\section{SOURCES OF EXPERIMENTAL DATA}

Abe, J. I., Nakanishi, K. and Touhara, H., 1978. J. Chem. Thermodyn., 10: 483 [DECHEMA Citation].

Ambrose, D., 1978. Vapor-Liquid Properties. National Physical Laboratory, UK.

Anderson, J. M., Barrick, M. W. and Robinson, R. L., Jr., 1988. Solubilities of carbon dioxide in cyclohexane and trans-decalin at pressures to $10.7 \mathrm{MPa}$ and temperatures from 323 to 423 K. J. Chem. Eng. Data, 31: 172.

API Monograph Series, March, 1979. Four-Ring Condensed Aromatic Compounds. Washington D.C., American Petroleum Institute, Monograph No. 709.

AspenTech, 1995. Aspen Plus, Release 9.1-3. Cambridge, Massachusetts.

Azarnoosh, A. and McKetta, J. J., 1963. Nitrogen-n-decane system in the two-phase region. J. Chem. Eng. Data, 8: 494.

Bader, M., 1993. Vapor-Liquid Equilibrium Properties of Aqueous and Supercritical Fluids at Infinite Dilution. Ph.D. Dissertation, Oklahoma State University, Stillwater, OK.

Barrick, M. W., Anderson, J. M. and Robinson, R. L., Jr., 1987. Solubilities of carbon dioxide in naphthalene, phenanthrene and pyrene at pressures to $10.6 \mathrm{MPa}$ and temperatures from 373 to 433 K. J. Chem. Eng. Data, 32: 372.

Berty, T. E., Reamer, H. H. and Sage, B. H., 1966. Phase behavior in the hydrogen-cyclohexane system. J. Chem. Eng. Data, 11: 25.

Brown, T. S., Niesen, V. G., Sloan, E. D. and Kidnay, A. J., 1989. Vapor-liquid equilibria for the binary systems of nitrogen, carbon dioxide and n-butane at temperatures from 220 to 344 K. Fluid Phase Equilibria, 53: 7.

Bufkin, B., 1986. High Pressure Solubilities of Carbon Dioxide and Ethane in Selected Paraffinic, Naphthenic and Aromatic Solvents. M. S. Thesis, Oklahoma State University, Stillwater, Oklahoma.

Byk, S. Sh., Serebrennaya, I. I. and Scherbakova, P. R., 1963. Khim. Prom-St., 7: 507 [DECHEMA Citation].

Chaudhary, M. M., Van Ness, H. C. and Abbott, M. M., 1980. J. Chem. Eng. Data, 25: 254 [DECHEMA Citation]. 
D'Avila, S. G. and Silva, R. S. F., 1970. J. Chem. Eng. Data, 15: 421 [DECHEMA Citation].

D’Avila, S. G. and Cotrim, M. L., 1973. Rev. Bras. Technol., 4: 191 [DECHEMA Citation].

DECHEMA Chemistry Data Series, 1977 and thereafter. DECHEMA, Frankfurt.

De Goede, R., Peters, C. J., Van Der Kooi, H. J. and Lichtenthaler, R. N., 1989. Phase equilibria in binary mixtures of ethane and hexadecane. Fluid Phase Equilibria, 50: 305.

Dobson, H. J. E., 1925. J. Chem. Soc., 2866 [DECHEMA Citation].

Ewert, M., 1936. Bull. Soc. Chim. Belg., 45: 493 [DECHEMA Citation].

Fall, D. J. and Luks, K. D., 1984. Phase equilibria behavior of the systems carbon dioxide $+\mathrm{n}-$ dotriacontane and carbon dioxide + n-docosane. J. Chem. Eng. Data, 29: 413.

Filippov, V. V., Markuzin, N. P. and Sazonov, V. P., 1977. Zh. Prikl. Khim. (Leningrad), 50: 1321 [DECHEMA Citation].

Freeman, J. R. and Wilson, G. M., 1985. AIChE Symposium Series, 81 (244): 14 [DECHEMA Citation].

Gasem, K. A. M., 1986. Binary Vapor-Liquid Phase Equilibrium for Carbon Dioxide + Heavy Normal Paraffins. Ph. D. Dissertation, Oklahoma State University, Stillwater, Oklahoma.

Gasem, K. A. M., Ross, C. H. and Robinson, R. L., Jr., 1993. Prediction of ethane and $\mathrm{CO}_{2}$ solubilities in heavy normal paraffins using generalized-parameter Soave and PengRobinson equations of state. Can. J. Chem. Eng., 71: 805.

Gorodetsky, J. Ya. and Olevsky, V. M., 1960. Vestnik Leningrad Univ. 15, Ser. Fiz. I Khim., 102 [DECHEMA Citation].

Griswold, J. and Wong, S. Y., 1952. Chem. Eng. Progr. Symposium Series, 48: 18 [DECHEMA Citation].

Gromov, G. P., Movzumsade, M. M. and Sadykov, R. K., 1969. Izv. Vyssh. Uceb. Zaved. Neft. Gaz., 12: 57. [DECHEMA Citation].

Inomata, H., Arai, L. and Saito, S., 1987. Vapor-liquid equilibria for $\mathrm{CO}_{2}+$ hydrocarbon mixtures at elevated temperatures and pressures. Fluid Phase Equilibria, 36: 107. 
Jackowski, A. W., 1980. Pol. J. Chem., 54: 1765 [DECHEMA Citation].

Kharin, S. E., Perelygin, V. M. and Volkov, A. G., 1968. Izv. Vyssh. Ucheb. Zaved., Pishch. Tekhnol., 4: 136 [DECHEMA Citation].

Kharin, S. E., Perelygin, V. M. and Remizov, G. P., 1969. Izv. Vyssh. Ucheb. Zaved., Khim. Khim. Tekhnol., 12: 424 [DECHEMA Citation].

Kim, J. Y., and Rousseau,R. W., 1985. Vapor-liquid equilibria for mixtures of methanol and methyl mercaptan. AIChE Symposium Series, 81 (244): 74.

Kim, C. H., Vimalchand, P. and Donohue, M. D., 1986. Vapor-liquid equilibria for binary mixtures of carbon dioxide with benzene, toluene and p-xylene. Fluid Phase Equilibria, 32: 299.

Klink, A. E., Cheh, H. Y. and Amick, E. H., Jr., 1975. The vapor-liquid equilibrium of the hydrogen-n-butane system at elevated pressures. AICHE J., 21: 1142.

Kooner, Z. S., Phutela, R. C. and Fenby, D. V., 1980. Aust. J. Chem., 33: 9 [DECHEMA Citation].

Laird, D. G. and Howat, C. S., 1990. Vapor-liquid phase equilibria and molar volumes of the butadiene-acetonitrile system from 300 to 355 K. Fluid Phase Equilibria, 60: 173.

Lawrence, D. R. and Swift, G. W., 1974. Vapor-liquid equilibria in three binary and ternary systems composed of n-butane, butene-1 and butadiene-1,3. J. Chem. Eng. Data, 19: 61.

Lhotak, V. and Wichterle, I., 1981. Vapor-liquid equilibrium in the ethane-n-butane system at high pressures. Fluid Phase Equilibria, 6: 229.

Lieberwirth, I. and Schuberth, H., 1979. Z. Phys. Chem. (Leipzig), 260: 669 [DECHEMA Citation].

Lin, H. M., Kim, H. and Chao, K. C., 1981. Gas-liquid equilibria in nitrogen + n-hexadecane mixtures at elevated temperatures and pressures. Fluid Phase Equilibria, 7: 181.

Lin, H. M., Sebastian, H. M., and Chao, K. C., 1980. Gas-liquid equilibrium in hydrogen + nhexadecane and methane $+\mathrm{n}$-hexadecane at elevated temperatures and pressures. J. Chem. Eng. Data, 25: 252.

Llave, F. M. and Chung, T. H., 1988. Vapor-liquid equilibria of nitrogen-hydrocarbon systems at elevated pressures. J. Chem. Eng. Data, 33: 123. 
Malone, P. V. and Kobayashi, R., 1990. Light gas solubility in phenanthrene: The hydrogenphenanthrene and methane-phenanthrene systems. Fluid Phase Equilibria, 55: 193.

Mato, F. A. and Berro Charles, 1991. Vapor-liquid equilibria and excess volumes for binary systems of methyl tert-butyl ether (MTBE) with trans-1,2-dichloroethylene and acetonitrile. J. Chem. Eng. Data, 36: 262.

Nagarajan, N. and Robinson, R. J., Jr., 1987. Equilibrium phase compositions, phase densities and interfacial tensions for $\mathrm{CO}_{2}+$ hydrocarbon Systems, 3. $\mathrm{CO}_{2}+$ cyclohexane. 4. $\mathrm{CO}_{2}+$ benzene. J. Chem. Eng. Data, 32: 369.

Nagata, I., 1989. Isothermal (vapour + liquid) equilibria of (2-methylpropan-2-ol + acetonitrile) and (2-methylpropan-2-ol + acetonitrile + benzene). J. Chem Thermodynamics, 21: 225.

Nath, A. and Bender, E., 1983. J. Chem. Eng. Data, 28: 370 [DECHEMA Citation].

Ohgaki, K., Sano, F. and Katayama, T., 1976. Isothermal vapor-liquid equilibrium data for binary systems containing ethane at high pressures. J. Chem. Eng. Data, 21: 55.

Oracz, P., 1989. Int. Data Series, Selected Data on Mixtures, Series A, 286.

Panagiotopoulos, A. Z. and Reid, R. C., 1986. New mixing rules for cubic equations of state for highly polar asymmetric mixtures. ACS Symposium Series, 300: 571.

Park, J. K., 1993. Binary Vapor-Liquid Equilibrium Measurements for Selected Asymmetric Mixtures and Equation of State Development. Ph. D. Dissertation, Oklahoma State University, Stillwater, Oklahoma.

Peters, C. J., Spiegelaar, J. and De Swaan Arons, J., 1988. Phase equilibrium in binary mixtures of ethane + docosane and molar volumes of liquid docosane. Fluid Phase Equilibria, 41: 245.

Polak, Jiri, Murakami, S., Lam, V. T., Pflug, H. D. and Benson, G. C., 1970. Molar excess enthalpies, volumes, and Gibbs free energies of methanol - isomeric butanol systems at 25 ${ }^{\circ}$ C. Can. J. Chem., 48: 2457.

Pozo de Fernandez, M. E. Zollweg, J. A. and Streett, W. B., 1989. Vapor-liquid equilibrium in the binary system carbon dioxide + n-butane. J. Chem. Eng. Data, 34: 324.

Rafflenbeul, L. and Hartmann, H., 1978. Chem. Techn., 7: 145 [DECHEMA Citation]. 
Reamer, H. H. and Sage, B. H., 1963. Phase equilibria in hydrocarbon systems. volumetric and phase behavior of the n-decane- $\mathrm{CO}_{2}$ System. 8: 508 .

Reid, R. C., Prausnitz, J. M. and Sherwood, T. K., 1977. The Properties of Gases and Liquids, $2^{\text {nd }}$ Edition, McGraw-Hill, New York.

Richon, D., Laugier, S. and Renon, H., 1991. High-pressure vapor-liquid equilibria for binary mixtures containing a light paraffin and an aromatic compound or a naphthene in the range 313-473 K. J. Chem. Eng. Data, 36: 104.

Robinson, R. L., Jr. and Gasem, K. A. M., 1987. Phase behavior of coal fluids: Data for correlation development. DE-FG22-83PC60039-12, Final Report, Department of Energy.

Sazonov, V. P., 1986. Zh. Prikl. Khim. (Leningrad), 59: 1451 [DECHEMA Citation].

Scatchard, G. and Wilson, G. M., 1964. J. Am. Chem. Soc., 86: 133 [DECHEMA Citation].

Schuberth, H., 1964. Z. Phys. Chem. (Leipzig), 225: 305 [DECHEMA Citation].

Sebastian, H. M., Simnick, J. J., Lin, H. and Chao, K. C., 1980. Vapor-liquid equilibrium in binary mixtures of carbon dioxide $+n$-decane and carbon dioxide $+n$-hexadecane. $J$. Chem. Eng. Data, 25: 138.

Sebastian, H. M., Simnick, J. J., Lin, H. M., and Chao, K. C., 1980. Gas-liquid equilibrium in the hydrogen $+\mathrm{n}$-decane systems at elevated temperatures and pressures. J. Chem. Eng. Data, 25: 68 .

Shibata, S. K. and Sandler, S. I., 1989. High-pressure vapor-liquid equilibria of mixtures of nitrogen, carbon dioxide and cyclohexane. J. Chem. Eng. Data, 34: 419.

Signer, R., Arm, H. and Daeniker, H., 1969. Helv. Chim. Acta, 52: 2347 [DECHEMA Citation].

Simnick, J. J., Sebastian, H. M., Lin, H. M. and Chao, K. C., 1978. Solubility of hydrogen in toluene at elevated temperatures and pressures. J. Chem. Eng. Data, 23: 339.

Sugi, H. and Katayama, T., 1978. J. Chem. Eng. Jpn., 11: 167 [DECHEMA Citation].

Tong, J., 1994. Solubility Data for Nitrogen in n-Paraffins and Equation of State Methods to Describe Light Gas Solubilities in Hydrocarbons. M. S. Thesis, Oklahoma State University, Stillwater, Oklahoma. 
Tunik, E. K. and Zharov, V. T., 1980. Viniti, 1242 [DECHEMA Citation].

Villamanan, M. A., Allawi, A. J., Van Ness, H. C., 1984. J. Chem. Eng. Data, 29: 431 [DECHEMA Citation].

Wilson, S. R., Patel, R. B., Abbott, M. M. and Van Ness, H. C., 1979. J. Chem. Eng. Data, 24 : 130 [DECHEMA Citation].

Wresky, M., 1913. Z. Phys. Chem., 81: 1 [DECHEMA Citation].

Zharov, V. T. and Pervukhin, O. K., 1972. Zh. Fiz. Khim., 46: 1970 [DECHEMA Citation].

Zou, M. and Prausnitz, J. M., 1987. J. Chem. Eng. Data, 32: 34 [DECHEMA Citation].

Zudkevitch, D., Forman, A. L. and Deatherage,W. G., 1990. Vapor-Liquid equilibrium in binary mixtures of ortho-dichlorobenzene + n-methyl-2-pyrrolidone and methanol + dimethyl disulfide. AIChE Symposium Series, 86 (279): 47. 


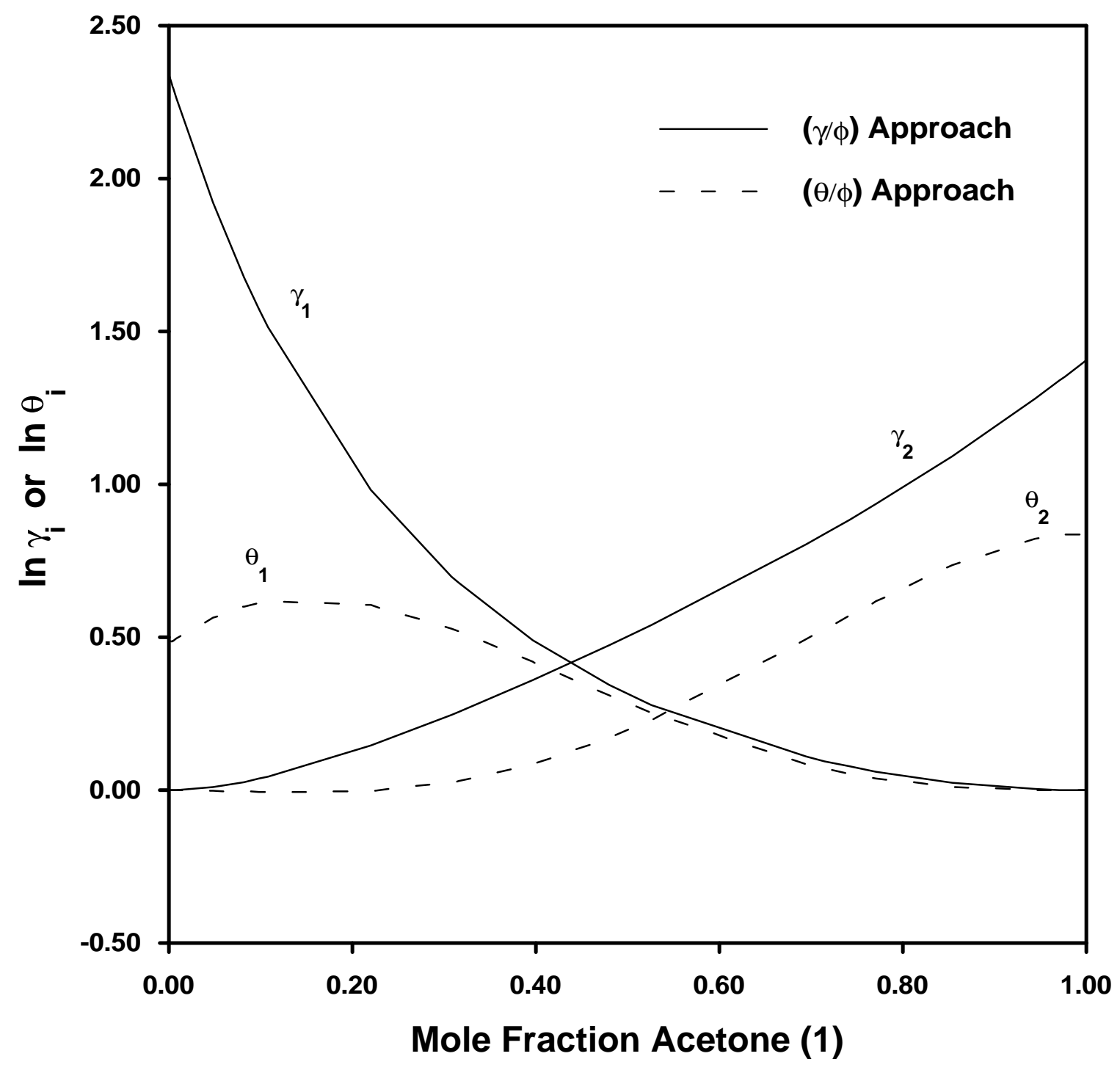

Figure 1. Comparison of Deviation Functions Generated from the $(\gamma / \phi)$ Approach and the $(\theta / \phi)$ Approach for the Acetone (1) + Water (2) System at 373.2 K 

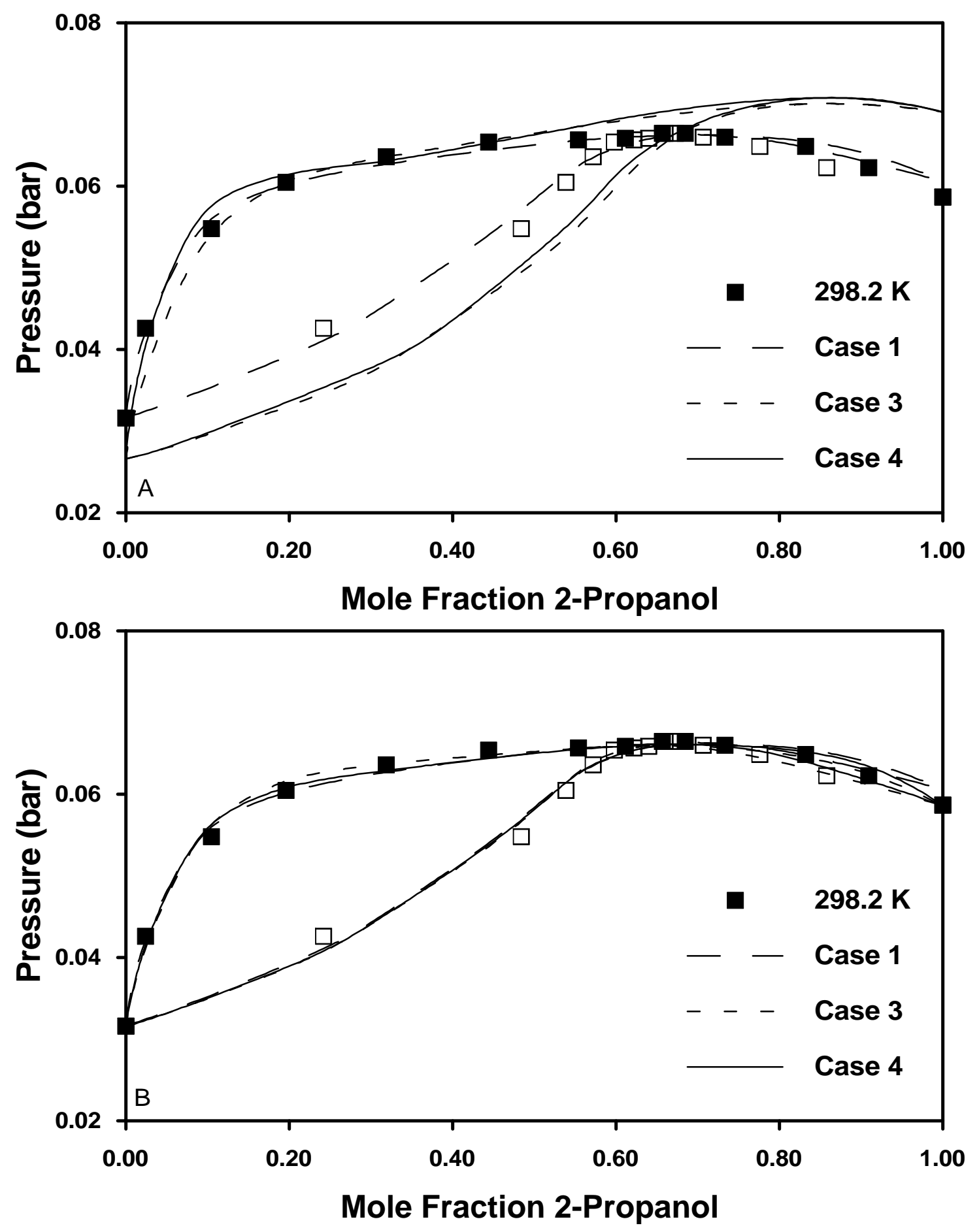

Figure 2. Representation of Vapor-Liquid Equilibrium of the 2-Propanol + Water System at 298.2 K for the Cases Studied. Experimental Data are from Sazonov (1986)

Figure 2(A): No Tuning of Pure Component EOS Parameters for Case 3 and Case 4

Figure 2(B): Tuned Pure Component EOS Parameters for Case 3 and Case 4 


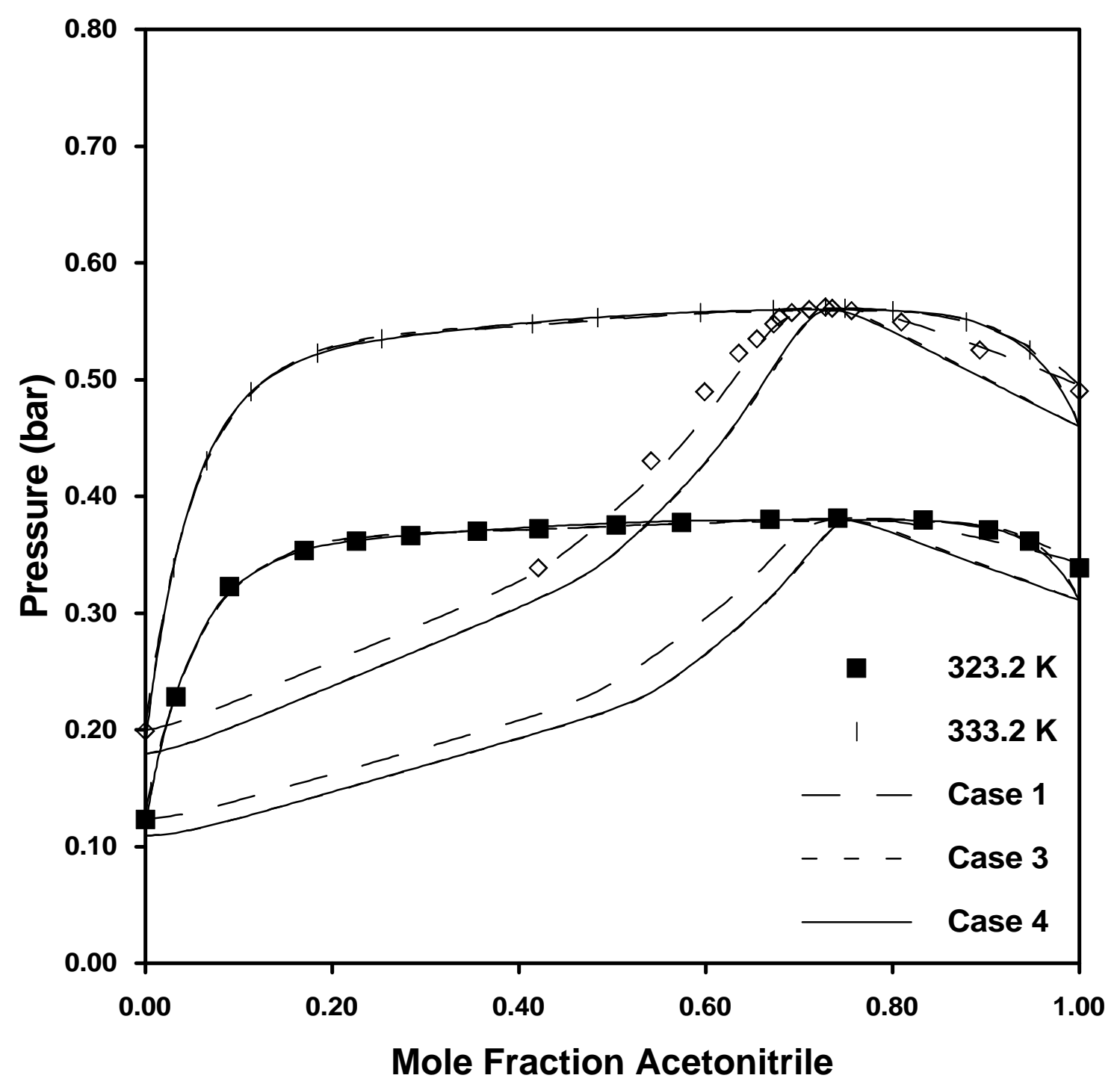

Figure 3. Representation of Vapor-Liquid Equilibrium of the Acetonitrile + Water System for the Cases Studied. Experimental Data at 323.2 K are from Wilson et al. (1979) and at $333.2 \mathrm{~K}$ are from Sugi and Katayama (1983). 

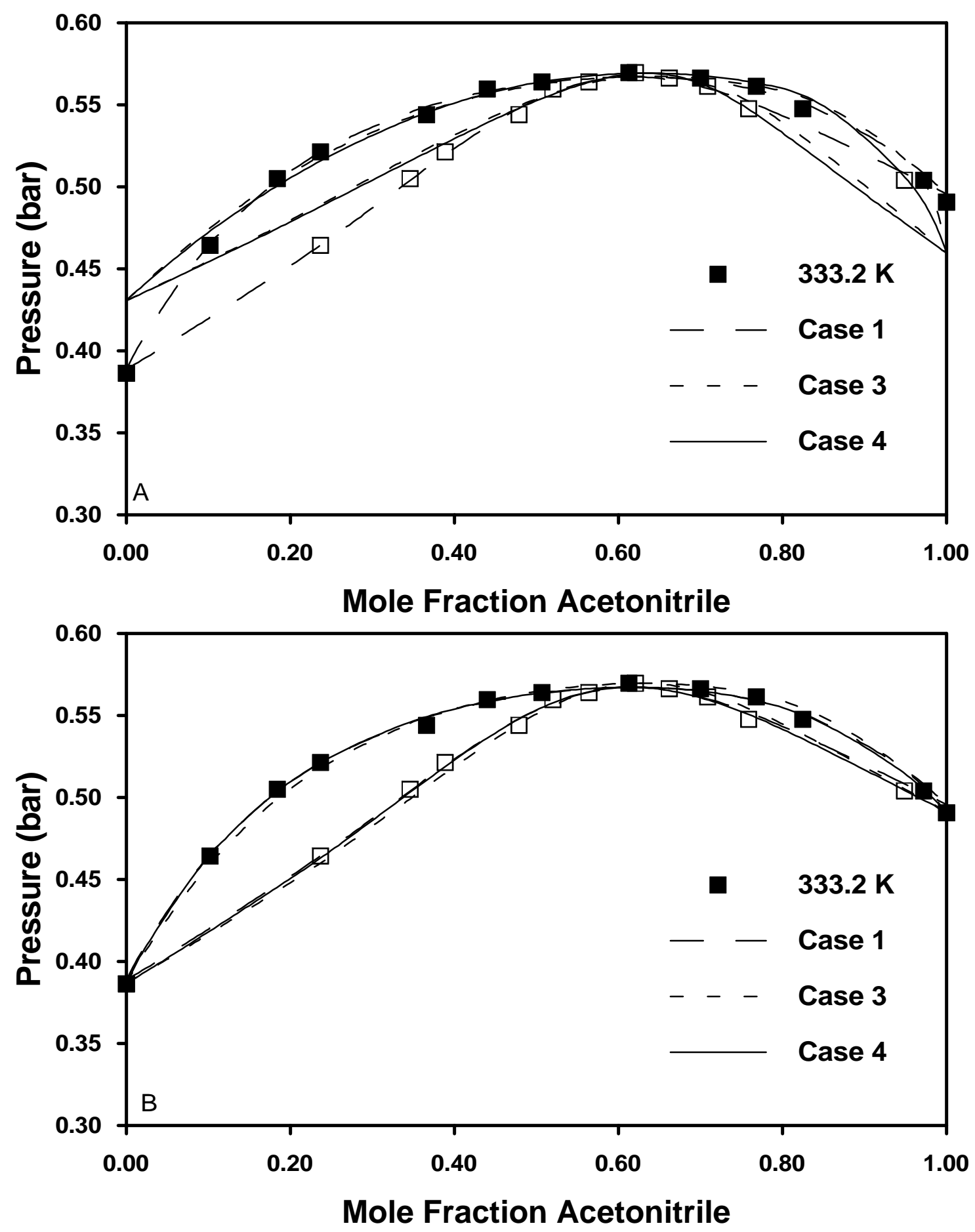

Figure 4. Representation of Vapor-Liquid Equilibrium of the Acetonitrile + Tert-Butanol System for the Cases Studied. Experimental Data are from Nagata (1989)

Figure 5(A): No Tuning of Pure Component EOS Parameters for Case 3 and Case 4 Figure 5(B): Tuned Pure Component EOS Parameters for Case 3 and Case 4 


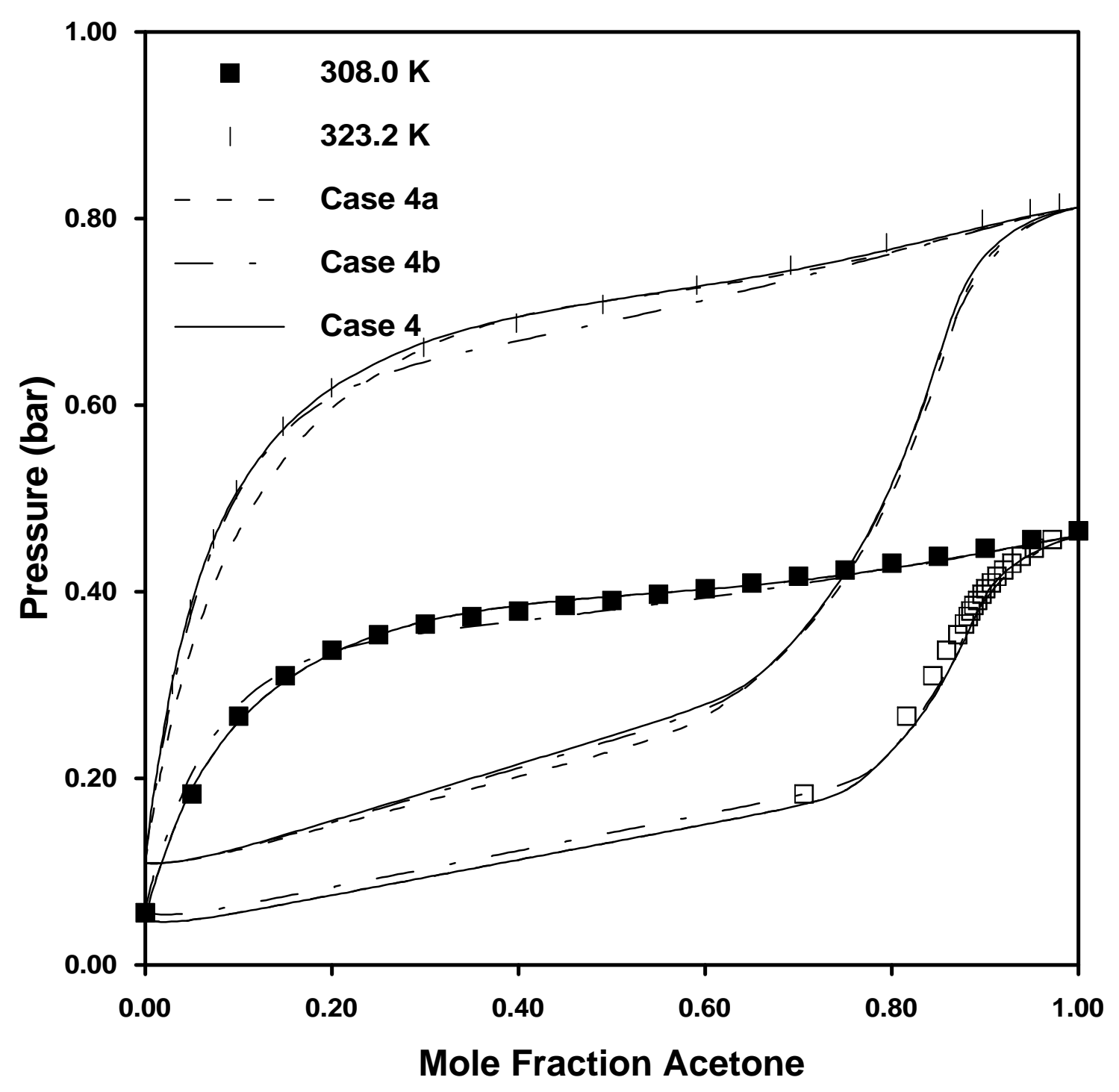

Figure 5. Representation of Vapor-liquid Equilibrium of the Acetone + Water System at 308.2 K and 323.2 K Using the $(\theta / \phi)$ Approach. Experimental Data at $308.2 \mathrm{~K}$ are from Lieberwerth and Schuberth (1979) and at 323.2 K are from Chaudhary et al. (1980) 


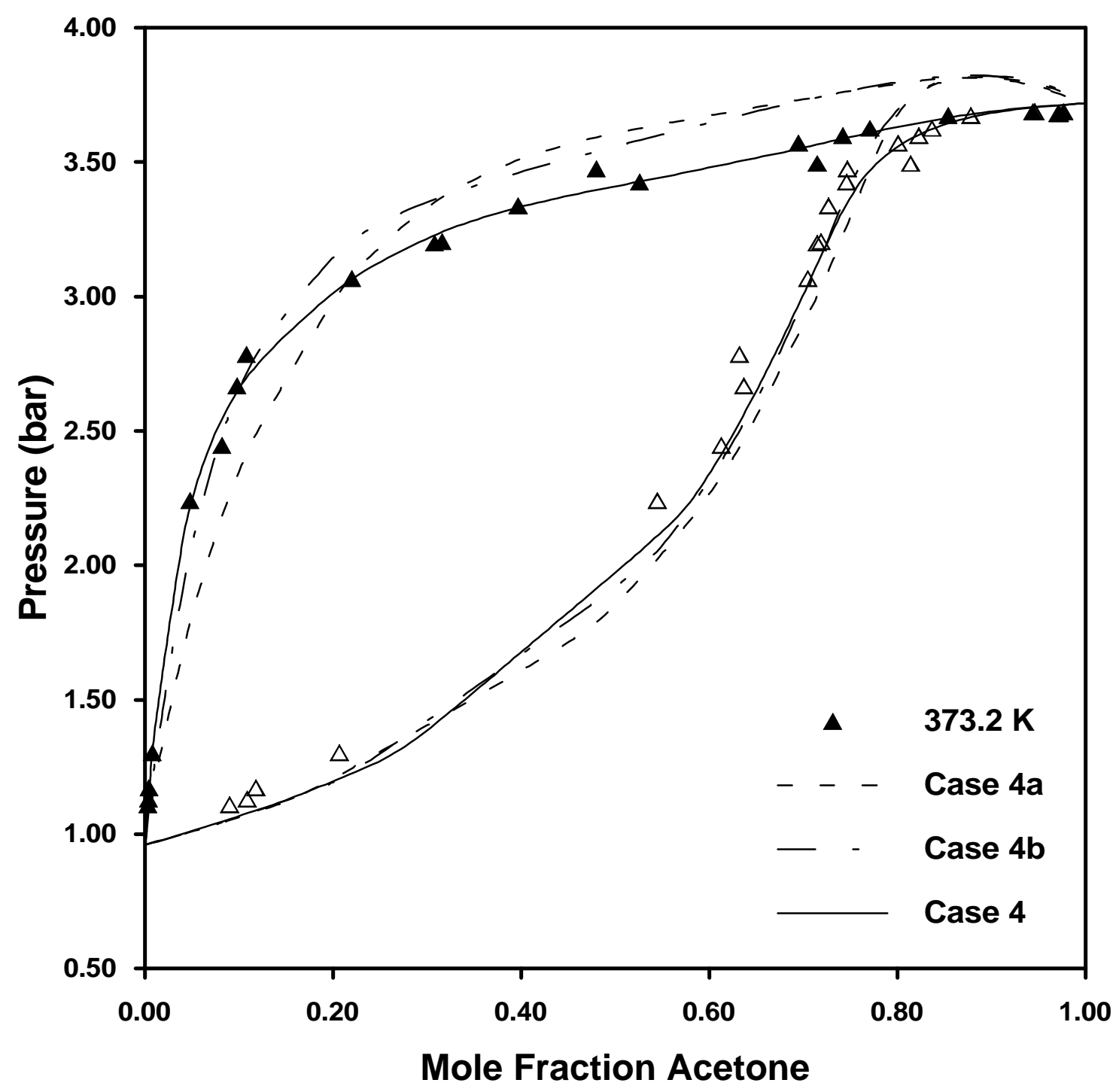

Figure 6. Representation of Vapor-liquid Equilibrium of the Acetone + Water System at 373.2 K Using the $(\theta / \phi)$ Approach. Experimental Data are from Griswold and Wong (1952) 


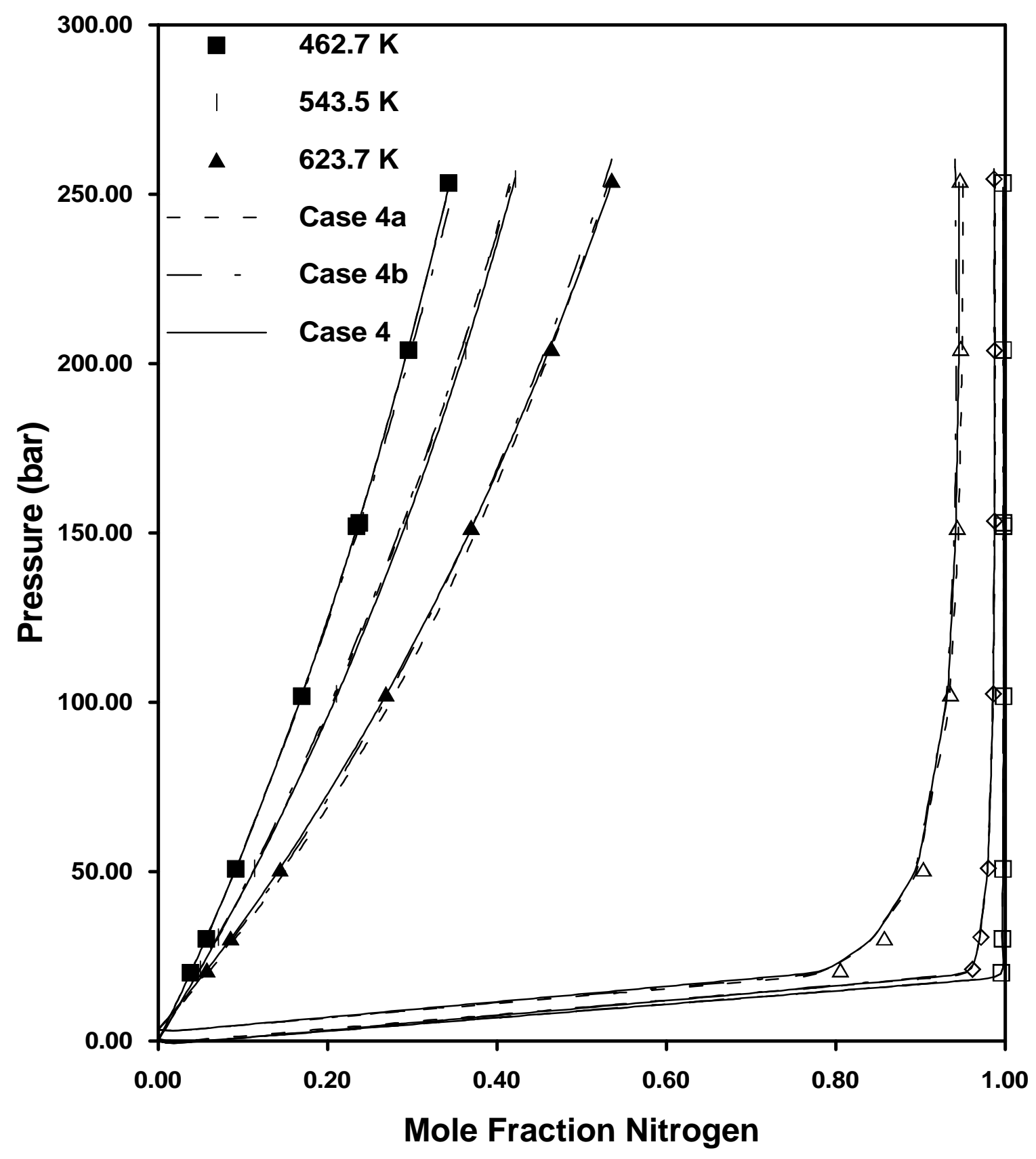

Figure 7. Representation of Vapor-Liquid Equilibrium of the Nitrogen + n-Hexadecane System Using the $(\theta / \phi)$ Approach. Experimental Data are from Lin et al. (1981) 


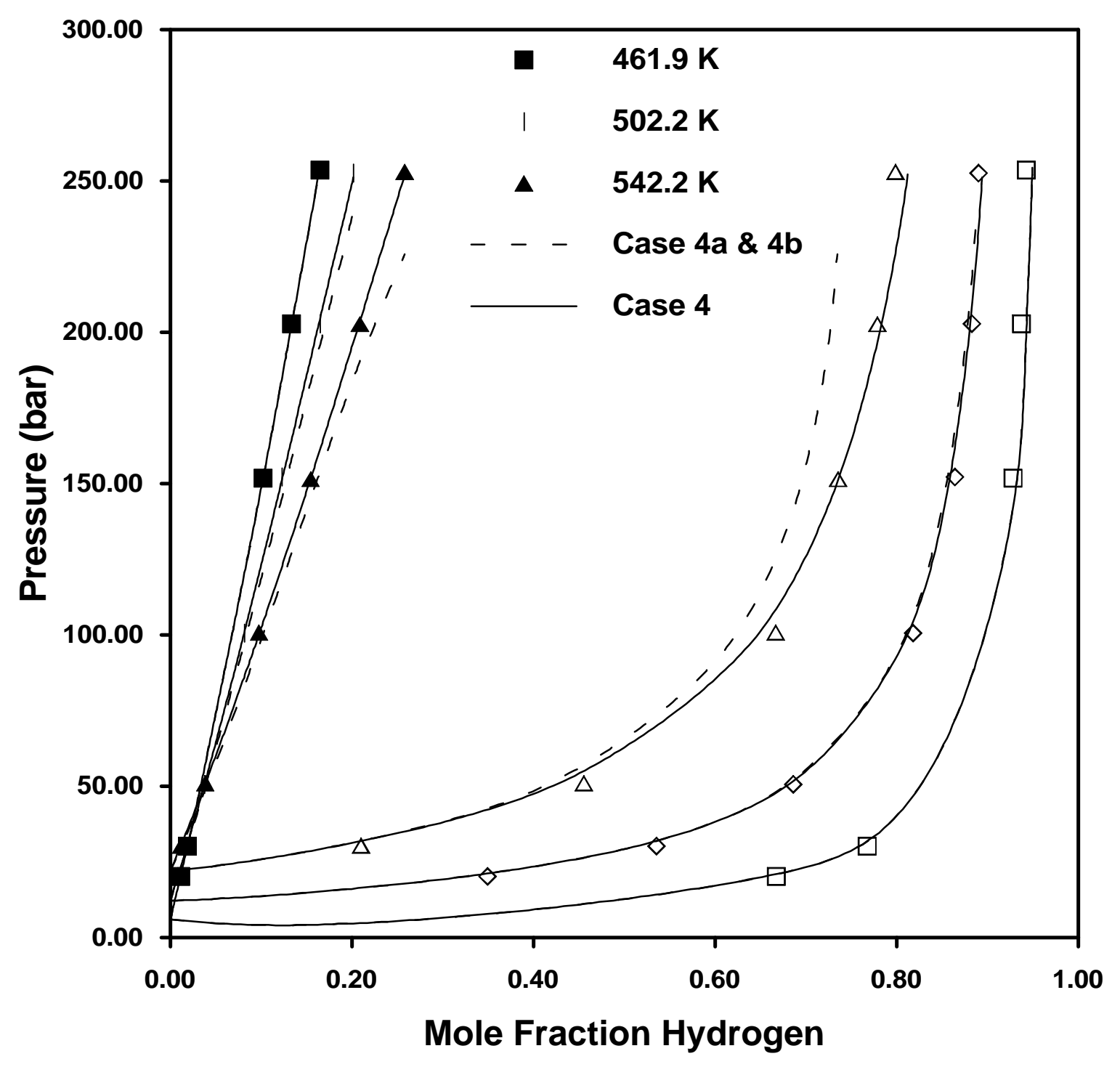

Figure 8. Representation of Vapor-Liquid Equilibrium of the Hydrogen + Toluene System Using the $(\theta / \phi)$ Approach. Experimental Data are from Simnick et al. (1978) 
Table 1

Cases studied in model evaluations

\begin{tabular}{l} 
Case \\
\hline 1 \\
The Split $(\gamma / \phi)$ Approach \\
Peng-Robinson equation of state with the van der Waals mixing rules (with \\
no interaction parameter) for the vapor phase and the NRTL model for the \\
liquid phase. This case is used for highly nonideal low pressure systems \\
only. \\
The $(\phi / \phi)$ Approach with the van der Waals Mixing Rules \\
Peng-Robinson equation of state using the van der Waals mixing rules with \\
two interaction parameters $\left(\mathrm{C}_{\mathrm{ij}}\right.$ and $\left.\mathrm{D}_{\mathrm{ij}}\right)$. This case is used for systems at \\
high pressure only. \\
The $(\phi / \phi)$ Approach with the MWS Mixing Rules \\
Peng-Robinson equation of state with the MWS mixing rules. Excess \\
model used with the mixing rules is the modified NRTL model. \\
The New $(\theta / \phi)$ Approach \\
$\begin{array}{l}\text { Peng-Robinson equation of state using the van der Waals mixing rules with } \\
\text { one interaction parameter }\left(\mathrm{C}_{\mathrm{ij}}\right) \text {, and a fugacity deviation function correction } \\
\text { applied to the calculated liquid fugacity. The Redlich-Kister model is used } \\
\text { for the fugacity deviation function. }\end{array}$
\end{tabular}


Table 2

Low pressure binary VLE data used in model calculations

\begin{tabular}{|c|c|c|c|c|c|}
\hline System & $\begin{array}{l}\text { Temperature } \\
\text { Range }(\mathrm{K})\end{array}$ & $\begin{array}{l}\text { Pressure Range } \\
\text { (Bar) }\end{array}$ & $\begin{array}{l}\text { First } \\
\text { Component } \\
\text { Liquid Mole } \\
\text { Fraction Range } \\
\end{array}$ & $\begin{array}{l}\text { First } \\
\text { Component } \\
\text { Vapor Mole } \\
\text { Fraction Range } \\
\end{array}$ & Reference \\
\hline $\begin{array}{l}\text { Methanol + } \\
\text { Water }\end{array}$ & $\begin{array}{l}298.2 \\
313.1 \\
318.2\end{array}$ & $\begin{array}{l}0.0420-0.1615 \\
0.1404-0.3134 \\
0.1813-0.4077\end{array}$ & $\begin{array}{l}0.0444-0.9361 \\
0.1499-0.8607 \\
0.1220-0.8390\end{array}$ & $\begin{array}{l}0.2777-0.9817 \\
0.6279-0.9572\end{array}$ & $\begin{array}{l}\text { Kooner et al. (1980) } \\
\text { Wresky (1913) } \\
\text { Zharov and Pervukhin (1972) }\end{array}$ \\
\hline $\begin{array}{l}\text { Ethanol + } \\
\text { Water }\end{array}$ & $\begin{array}{l}298.2 \\
303.2- \\
308.2\end{array}$ & $\begin{array}{l}0.0442-0.0774 \\
0.0720-0.1326\end{array}$ & $\begin{array}{l}0.0523-0.7810 \\
0.1000-0.9000\end{array}$ & $0.3164-0.8161$ & $\begin{array}{l}\text { Dobson (1925) } \\
\text { D'Avila and Cotrim (1973) }\end{array}$ \\
\hline $\begin{array}{l}\text { 2- } \\
\text { Propanol + } \\
\text { Water }\end{array}$ & $\begin{array}{l}298.2 \\
328.2\end{array}$ & $\begin{array}{l}0.0426-0.0665 \\
0.2337-0.3353\end{array}$ & $\begin{array}{l}0.0240-0.9097 \\
0.0320-0.7300\end{array}$ & $\begin{array}{l}0.2420-0.8580 \\
0.4190-0.7230\end{array}$ & $\begin{array}{l}\text { Sazonov (1986) } \\
\text { Tunik and Zharov (1980) }\end{array}$ \\
\hline $\begin{array}{l}\text { Water }+ \\
\text { 1-Butanol }\end{array}$ & $\begin{array}{l}323.2- \\
403.2\end{array}$ & $0.0707-3.3160$ & $0.0776-0.9951$ & $0.2970-0.9247$ & Kharin et al. (1969) \\
\hline $\begin{array}{l}\text { Water }+ \\
\text { 2-Pentanol }\end{array}$ & $\begin{array}{l}343.2- \\
363.2\end{array}$ & $0.1485-0.9250$ & $0.0160-0.9990$ & & Zou and Prausnitz (1987) \\
\hline $\begin{array}{l}\text { Water }+ \\
\text { 1-Hexanol }\end{array}$ & $\begin{array}{l}294.2- \\
313.2\end{array}$ & $0.0080-0.0759$ & $0.0540-0.9990$ & $0.8370-0.9860$ & Filippov et al. (1977) \\
\hline
\end{tabular}




\section{Table 2 (Continued)}

\begin{tabular}{|c|c|c|c|c|c|}
\hline System & $\begin{array}{l}\text { Temperature } \\
\text { Range }(\mathrm{K})\end{array}$ & $\begin{array}{l}\text { Pressure Range } \\
\text { (Bar) }\end{array}$ & $\begin{array}{l}\text { First Component } \\
\text { Liquid Mole } \\
\text { Fraction Range }\end{array}$ & $\begin{array}{l}\text { First Component } \\
\text { Vapor Mole } \\
\text { Fraction Range }\end{array}$ & Reference \\
\hline $\begin{array}{l}\text { Allyl Alcohol + } \\
\text { Water }\end{array}$ & $294.2-313.2$ & $0.0377-0.1128$ & $0.1740-0.7880$ & & Ewert (1936) \\
\hline $\begin{array}{l}\text { Water }+ \\
\text { 2-Butoxyethanol }\end{array}$ & $278.2-358.2$ & $0.0019-0.5944$ & $0.0703-0.8986$ & $0.7193-0.9880$ & Scatchard and Wilson (1964) \\
\hline $\begin{array}{l}\text { Water }+ \\
\text { Cyclohexanol }\end{array}$ & 363.2 & $0.1397-0.7451$ & $0.0180-0.9980$ & $0.4350-0.9770$ & Gorodetsky and Olevsky (1960) \\
\hline $\begin{array}{l}\text { Water }+ \\
\text { Acetic Acid }\end{array}$ & $372.8-412.6$ & $0.6205-3.5922$ & $0.0313-0.9937$ & $0.0582-0.9953$ & Freeman and Wilson (1985) \\
\hline $\begin{array}{l}\text { Water + } \\
\text { Propionic Acid }\end{array}$ & $333.2-373.2$ & $0.0491-1.0296$ & $0.0080-0.9850$ & $0.0419-0.9850$ & $\begin{array}{l}\text { Rafflenbeul and Hartmann } \\
\text { (1978) }\end{array}$ \\
\hline \multirow[t]{3}{*}{$\begin{array}{l}\text { Acetone + } \\
\text { Water }\end{array}$} & 308.2 & $0.1833-0.4561$ & $0.0500-0.9500$ & $0.7060-0.9720$ & $\begin{array}{l}\text { Lieberwirth and Schuberth } \\
\text { (1979) }\end{array}$ \\
\hline & 323.2 & $0.3005-0.8170$ & $0.0290-0.9796$ & & Chaudhary et al. (1980) \\
\hline & 373.2 & $1.1101-3.6887$ & $0.0033-0.9770$ & $0.0902-0.9780$ & Griswold and Wong (1952) \\
\hline $\begin{array}{l}\text { 2-Butanone + } \\
\text { Water }\end{array}$ & 333.2 & $0.3718-0.6146$ & $0.0134-0.9250$ & & Zou and Prausnitz (1987) \\
\hline
\end{tabular}


Table 2 (Continued)

\begin{tabular}{|c|c|c|c|c|c|}
\hline System & $\begin{array}{l}\text { Temperature } \\
\text { Range }(\mathrm{K})\end{array}$ & $\begin{array}{l}\text { Pressure Range } \\
\text { (Bar) }\end{array}$ & $\begin{array}{l}\text { First Component } \\
\text { Liquid Mole } \\
\text { Fraction Range }\end{array}$ & $\begin{array}{l}\text { First Component } \\
\text { Vapor Mole } \\
\text { Fraction Range }\end{array}$ & Reference \\
\hline $\begin{array}{l}\text { Di-Ethyl Ether + } \\
\text { Water }\end{array}$ & $\begin{array}{l}298.2 \\
308.2\end{array}$ & $\begin{array}{l}0.1727-0.7189 \\
0.1876-1.0466\end{array}$ & $\begin{array}{l}0.0020-0.9900 \\
0.0014-0.9901\end{array}$ & & $\begin{array}{l}\text { Signer et al. (1969) } \\
\text { Villamanan et al. (1984) }\end{array}$ \\
\hline $\begin{array}{l}\text { Acetonitrile + } \\
\text { Water }\end{array}$ & $\begin{array}{l}323.2 \\
333.2\end{array}$ & $\begin{array}{l}0.2283-0.3815 \\
0.4305-0.5622\end{array}$ & $\begin{array}{l}0.0328-0.9472 \\
0.0300-0.9471\end{array}$ & $0.4209-0.8939$ & $\begin{array}{l}\text { Wilson et al. (1979) } \\
\text { Sugi and Katayama (1978) }\end{array}$ \\
\hline $\begin{array}{l}\text { Water }+ \\
\text { Ethanolamine }\end{array}$ & $333.2-364.9$ & $0.0131-0.6910$ & $0.0690-0.9440$ & & Nath and Bender (1983) \\
\hline $\begin{array}{l}\text { Tetrahydrofuran + } \\
\text { Water }\end{array}$ & 298.2 & $0.1547-0.2223$ & $0.0500-0.9500$ & & Signer et al. (1969) \\
\hline $\begin{array}{l}\text { Acetaldehyde + } \\
\text { Water }\end{array}$ & $\begin{array}{l}283.2-303.2 \\
373.2\end{array}$ & $\begin{array}{l}0.2398-1.3350 \\
1.7732-4.8636\end{array}$ & $\begin{array}{l}0.1000-0.9000 \\
0.0100-0.1500\end{array}$ & $0.4800-0.7950$ & $\begin{array}{l}\text { D'Avila and Silva (1970) } \\
\text { Byk et al. (1963) }\end{array}$ \\
\hline $\begin{array}{l}\text { Water }+ \\
\text { Nitromethane }\end{array}$ & $\begin{array}{l}294.2-313.2 \\
323.2\end{array}$ & $\begin{array}{l}0.0367-0.1667 \\
0.1713-0.2623\end{array}$ & $\begin{array}{l}0.0340-0.9940 \\
0.0330-0.9970\end{array}$ & $\begin{array}{l}0.2560-0.8270 \\
0.1090-0.9650\end{array}$ & $\begin{array}{l}\text { Filippov et al. (1977) } \\
\text { Schuberth (1964) }\end{array}$ \\
\hline $\begin{array}{l}\text { Water }+ \\
\text { 2-Methylpyridine }\end{array}$ & $298.2-318.2$ & $0.0217-0.1079$ & $0.1270-0.9531$ & & Abe et al. (1978) \\
\hline
\end{tabular}


Table 2 (Continued)

\begin{tabular}{|c|c|c|c|c|c|}
\hline System & $\begin{array}{l}\text { Temperature } \\
\text { Range }(\mathrm{K})\end{array}$ & $\begin{array}{l}\text { Pressure Range } \\
\text { (Bar) }\end{array}$ & $\begin{array}{l}\text { First Component } \\
\text { Liquid Mole } \\
\text { Fraction Range }\end{array}$ & $\begin{array}{l}\text { First Component } \\
\text { Vapor Mole } \\
\text { Fraction Range }\end{array}$ & Reference \\
\hline $\begin{array}{l}\text { Ethyl Acetate + } \\
\text { Water }\end{array}$ & $323.2-353.2$ & $0.1707-1.3506$ & $0.0021-0.9439$ & $0.2207-0.8565$ & Kharin et al. (1968) \\
\hline $\begin{array}{l}\text { Acetonitrile + } \\
\text { tert-Butanol }\end{array}$ & 333.2 & $0.4645-0.5700$ & $0.1020-0.9720$ & $0.2370-0.9490$ & Nagata (1989) \\
\hline $\begin{array}{l}\text { 1,3-Butadiene }+ \\
\text { Acetonitrile }\end{array}$ & $305.0-329.9$ & $0.7260-6.3950$ & $0.0560-0.9130$ & & Laird and Howat (1990) \\
\hline $\begin{array}{l}\text { Methyl tert-Butyl } \\
\text { Ether + Acetonitrile }\end{array}$ & 313.2 & $0.2565-0.6102$ & $0.0122-0.9902$ & $0.1237-0.9868$ & Mato and Berro (1991) \\
\hline $\begin{array}{l}\text { Methanol + } \\
\text { tert-Butanol }\end{array}$ & $\begin{array}{l}298.2 \\
313.2\end{array}$ & $\begin{array}{l}0.0612-0.1626 \\
0.1395-0.3457\end{array}$ & $\begin{array}{l}0.0773-0.9523 \\
0.0155-0.9658\end{array}$ & $0.1535-0.9880$ & $\begin{array}{l}\text { Polak et al. (1970) } \\
\text { Oracz (1989) }\end{array}$ \\
\hline $\begin{array}{l}\text { tr-1,3-Pentadiene }+ \\
\text { Acetonitrile }\end{array}$ & $303.2-313.2$ & $0.3560-0.9466$ & $0.1000-0.9000$ & & Gromov et al. (1969) \\
\hline $\begin{array}{l}\text { Dimethyl Sulfide + } \\
\text { Methanol }\end{array}$ & $263.2-288.2$ & $0.0845-0.4501$ & $0.1042-0.9642$ & & Jackowski (1980) \\
\hline
\end{tabular}


Table 2 (Continued)

\begin{tabular}{llllll}
$\begin{array}{l}\text { System } \\
\text { Range (K) }\end{array}$ & $\begin{array}{l}\text { Temperature } \\
\text { (Bar) }\end{array}$ & $\begin{array}{l}\text { Pressure Range } \\
\text { Liquid Mole } \\
\text { Fraction Range }\end{array}$ & $\begin{array}{l}\text { First Component } \\
\text { Vapor Mole } \\
\text { Fraction Range }\end{array}$ & Reference \\
$\begin{array}{l}\text { Methyl Mercaptan }+ \\
\text { Methanol }\end{array}$ & $269.2-288.2$ & $0.2846-1.3884$ & $0.1078-0.9399$ & Kim and Rousseau (1985) \\
$\begin{array}{l}\text { Methyl Mercaptan }+ \\
\begin{array}{l}\text { Dimethyl Sulfide } \\
\text { 1-Butene }+\end{array}\end{array}$ & $310.9-338.7$ & $4.1640-8.6850$ & $0.1000-0.9000$ & $0.1051-0.9009$ & Lawrence and Swift (1974) \\
$\begin{array}{l}\text { 1,3-Butadiene } \\
\begin{array}{l}\text { Methanol + } \\
\text { Dimethyl DiSulfide }\end{array}\end{array}$ & $310.9-335.9$ & $0.2417-0.9619$ & $0.1221-0.9802$ & $0.7031-0.9734$ & Zuckowski (1980) \\
\hline
\end{tabular}


Table 3

Binary VLE data for ethane + hydrocarbons used in model evaluations

\begin{tabular}{llllll}
\hline Solvent & $\begin{array}{l}\text { Temperature } \\
\text { Range (K) }\end{array}$ & $\begin{array}{l}\text { Pressure } \\
\text { Range (Bar) }\end{array}$ & $\begin{array}{l}\text { Ethane Liquid } \\
\text { Mole Fraction } \\
\text { Range }\end{array}$ & $\begin{array}{l}\text { Ethane Vapor } \\
\text { Mole Fraction } \\
\text { Range }\end{array}$ & Reference \\
\hline n-Butane & $303.2-363.4$ & $4.41-53.26$ & $0.0440-0.8370$ & $0.1690-0.9510$ & $\begin{array}{l}\text { Lhotak and Wichterle (1981) } \\
\text { n-Decane }\end{array}$ \\
$\begin{array}{llll}\text { n-Hexadecane } \\
\text { n-Docosane }\end{array}$ & $311.1-411.1$ & $4.23-82.36$ & $0.1050-0.6380$ & & Dufkin (1986) \\
n-Octacosane & $320.0-360.0$ & $7.25-71.43$ & $0.0541-0.8530$ & & Peters et al. (1988) \\
n-Hexatriacontane & $373.2-423.2$ & $5.63-43.94$ & $0.1020-0.5200$ & & Robinson and Gasem (1987) \\
n-Tetratetracontane & $373.2-423.2$ & $3.68-47.60$ & $0.0870-0.5310$ & & Robinson and Gasem (1987) \\
Benzene & $323.2-423.2$ & $4.78-84.59$ & $0.0490-0.6000$ & & Robinson and Gasem (1987) \\
& 298.2 & $7.76-38.01$ & $0.1200-0.9300$ & & Bufkin (1986) \\
Toluene & $313.1-473.2$ & $6.30-114.80$ & $0.0270-0.9050$ & $0.3410-1.0000$ & Ohgaki et al. (1976) \\
Richon et al. (1991) \\
Cyclohthalene & $373.2-423.2$ & $21.45-104.28$ & $0.0850-0.4930$ & & Bufkin (1986) \\
Phenanthrene & $323.2-423.2$ & $3.26-77.71$ & $0.0490-0.6010$ & & Bufkin (1986) \\
Pyrene & $383.2-423.2$ & $22.64-116.53$ & $0.0810-0.3130$ & & Bufkin (1986) \\
\end{tabular}


Table 4

Binary VLE data for carbon dioxide + hydrocarbons used in model evaluations

\begin{tabular}{llllll}
\hline Solvent & $\begin{array}{l}\text { Temperature } \\
\text { Range }(\mathrm{K})\end{array}$ & $\begin{array}{l}\text { Pressure } \\
\text { Range (Bar) }\end{array}$ & $\begin{array}{l}\mathrm{CO}_{2} \text { Liquid Mole } \\
\text { Fraction Range }\end{array}$ & $\begin{array}{l}\mathrm{CO}_{2} \text { Vapor Mole } \\
\text { Fraction Range }\end{array}$ & Reference \\
\hline n-Butane & & & & & \\
n-Decane & $277.9-387.6$ & $3.45-62.12$ & $0.0390-0.7538$ & $0.1789-0.9636$ & $\begin{array}{l}\text { Pozo de Fernandez et al. (1989) } \\
\text { Reamer and Sage (1963). } \\
\text { n-Hexadecane }\end{array}$ \\
n-Docosane & $310.9-510.9$ & $6.89-86.18$ & $0.0450-0.8640$ & & Sebastian et al. (1980) \\
n-Octacosane & $323.2-373.2$ & $9.62-71.78$ & $0.0830-0.5930$ & & Fall and Luks (1984) \\
n-Hexatriacontane & $348.2-423.2$ & $8.07-96.04$ & $0.0700-0.6170$ & & Gasem (1986) \\
n-Tetratetracontane & $373.2-423.2$ & $5.24-86.53$ & $0.0620-0.5020$ & & Gasem (1986) \\
Benzene & 298.2 & $8.94-57.73$ & $0.1060-0.9130$ & $0.9815-0.9959$ & Gasem (1986) \\
& 344.3 & $68.95-109.20$ & $0.4530-0.8460$ & $0.9320-0.9410$ & Nagarajan and and (1976) \\
& 413.6 & $38.70-153.90$ & $0.1430-0.7010$ & $0.8660-0.9080$ & Inomata et al. (1987) \\
Toluene & $353.4-393.2$ & $5.20-64.50$ & $0.0190-0.3610$ & $0.7540-0.9800$ & Kim et al. (1986) \\
Naphthalene & $373.2-423.2$ & $13.90-104.50$ & $0.0470-0.3360$ & & Barrick et al. (1987) \\
Cyclohexane & $348.2-423.2$ & $19.80-104.30$ & $0.1030-0.5770$ & & Anderson et al. (1988) \\
Phenanthrene & $383.2-423.2$ & $18.80-106.20$ & $0.0470-0.2290$ & & Barrick et al. (1987) \\
Pyrene & 433.2 & $7.30-105.70$ & $0.0140-0.1720$ & & Barrick et al. (1987) \\
\hline
\end{tabular}


Table 5

Binary VLE data for nitrogen + hydrocarbons used in model evaluations

\begin{tabular}{llllll}
\hline Solvent & $\begin{array}{l}\text { Temperature } \\
\text { Range }(\mathrm{K})\end{array}$ & $\begin{array}{l}\text { Pressure } \\
\text { Range }(\mathrm{Bar})\end{array}$ & $\begin{array}{l}\mathrm{N}_{2} \text { Liquid Mole } \\
\text { Fraction Range }\end{array}$ & $\begin{array}{l}\mathrm{N}_{2} \text { Vapor Mole } \\
\text { Fraction Range }\end{array}$ & Reference \\
\hline & & & & & \\
n-Butane & $250.0-344.4$ & $4.83-157.85$ & $0.0040-0.2680$ & $0.1830-0.9840$ & Brown et al. (1989) \\
n-Decane & $310.9-410.9$ & $17.24-344.74$ & $0.0385-0.3980$ & $0.9270-1.0000$ & Azarnoosh and McKetta (1963) \\
n-Hexadecane & $462.7-623.7$ & $20.12-254.60$ & $0.0380-0.5360$ & $0.8060-0.9980$ & Lin et al. (1981) \\
n-Eicosane & $323.2-423.2$ & $38.25-172.29$ & $0.0610-0.2120$ & & Tong (1994) \\
n-Octacosane & $348.2-423.2$ & $42.99-164.71$ & $0.0730-0.2580$ & & Tong (1994) \\
n-Hexatriacontane & $373.2-423.2$ & $52.80-179.85$ & $0.1050-0.2970$ & & Tong (1994) \\
Benzene & $348.2-398.2$ & $62.11-307.12$ & $0.0345-0.2044$ & $0.9168-1.0000$ & Lin et al. (1981) \\
Toluene & $323.2-348.2$ & $36.40-353.50$ & $0.0180-0.1590$ & & Llave and Chung (1988) \\
Cyclohexane & $366.4-410.8$ & $17.53-275.93$ & $0.0090-0.2910$ & $0.7130-0.9720$ & Shibata and Sandler (1989) \\
\hline
\end{tabular}


Table 6

Binary VLE data for hydrogen + hydrocarbons used in model evaluations

\begin{tabular}{llllll}
\hline Solvent & $\begin{array}{l}\text { Temperature } \\
\text { Range }(\mathrm{K})\end{array}$ & $\begin{array}{l}\text { Pressure } \\
\text { Range }(\mathrm{Bar})\end{array}$ & $\begin{array}{l}\mathrm{H}_{2} \text { Liquid Mole } \\
\text { Fraction Range }\end{array}$ & $\begin{array}{l}\mathrm{H}_{2} \text { Vapor Mole } \\
\text { Fraction Range }\end{array}$ & Reference \\
\hline & & & & & \\
n-Butane & $327.7-394.3$ & $27.93-168.76$ & $0.0210-0.2660$ & $0.2130-0.9320$ & Klink et al. (1975) \\
n-Decane & $462.5-543.0$ & $19.26-255.14$ & $0.0251-0.3825$ & $0.6025-0.9891$ & Sebastian et al. (1980) \\
n-Hexadecane & $461.7-622.9$ & $20.09-252.71$ & $0.0311-0.4458$ & $0.8083-0.9995$ & Lin et al. (1980) \\
n-Eicosane & $323.2-423.2$ & $22.30-129.10$ & $0.0273-0.1289$ & & Park (1993) \\
n-Octacosane & $348.2-423.2$ & $28.60-131.00$ & $0.0452-0.1728$ & & Park (1993) \\
n-Hexatriacontane & $373.2-423.2$ & $35.60-167.50$ & $0.0677-0.2271$ & & Park (1993) \\
Benzene & $323.2-423.2$ & $25.50-157.30$ & $0.0103-0.0585$ & & Park (1993) \\
Toluene & $461.9-542.2$ & $30.30-253.72$ & $0.0082-0.2581$ & $0.2100-0.9430$ & Simnick et al. (1978) \\
Naphthalene & $373.2-423.2$ & $42.90-193.90$ & $0.0160-0.0570$ & & Park (1993) \\
Cyclohexane & $310.9-410.9$ & $34.47-551.58$ & $0.0125-0.2919$ & $0.8582-0.9973$ & Berty et al. (1966) \\
Phenanthrene & $398.2-473.2$ & $26.13-252.30$ & $0.0084-0.0840$ & & Malone and Koyabashi (1990) \\
Pyrene & 433.2 & $51.70-197.30$ & $0.0160-0.0580$ & & Park (1993) \\
\hline
\end{tabular}


Table 7

Physical properties used in model evaluations

\begin{tabular}{|c|c|c|c|c|}
\hline Compound & $\begin{array}{c}\mathrm{T}_{\mathrm{c}} \\
(\mathrm{K})\end{array}$ & $\begin{array}{r}\mathrm{p}_{\mathrm{c}} \\
(\mathrm{Bar}) \\
\end{array}$ & $\omega$ & Source \\
\hline Nitrogen & 126.3 & 33.9 & 0.039 & Ambrose (1978) \\
\hline Hydrogen & 33.2 & 13.0 & -0.218 & Reid et al. (1977) \\
\hline Ethane & 305.4 & 48.8 & 0.099 & Reid et al. (1977) \\
\hline Carbon Dioxide & 304.1 & 73.8 & 0.239 & Reid et al. (1977) \\
\hline n-Butane & 425.2 & 38.0 & 0.199 & Reid et al. (1977) \\
\hline n-Decane & 617.7 & 21.2 & 0.489 & Reid et al. (1977) \\
\hline n-Hexadecane & 722.0 & 14.1 & 0.742 & Reid et al. (1977) \\
\hline n-Eicosane & 770.5 & 11.2 & 0.874 & Gasem (1986) \\
\hline n-Docosane & 791.7 & 10.2 & 0.938 & Bader (1993) \\
\hline n-Octacosane & 845.4 & 8.3 & 1.107 & Gasem (1986) \\
\hline n-Hexatriacontane & 901.1 & 6.8 & 1.285 & Gasem (1986) \\
\hline n-Tetratetracontane & 944.3 & 6.0 & 1.418 & Gasem (1986) \\
\hline Cyclohexane & 553.5 & 40.7 & 0.212 & Reid et al. (1977) \\
\hline Benzene & 562.2 & 48.9 & 0.212 & Reid et al. (1977) \\
\hline Toluene & 591.8 & 41.0 & 0.263 & Reid et al. (1977) \\
\hline Naphthalene & 748.4 & 40.5 & 0.302 & Reid et al. (1977) \\
\hline Pyrene & 938.2 & 26.0 & 0.830 & Park (1993) \\
\hline Phenanthrene & 873.2 & 33.0 & 0.540 & API (1979) \\
\hline Water & 647.1 & 220.6 & 0.345 & AspenTech (1995) \\
\hline Methanol & 512.6 & 81.0 & 0.564 & AspenTech (1995) \\
\hline Ethanol & 513.9 & 61.5 & 0.645 & AspenTech (1995) \\
\hline 2-Propanol & 508.3 & 47.6 & 0.668 & AspenTech (1995) \\
\hline 1-Butanol & 563.1 & 44.2 & 0.593 & AspenTech (1995) \\
\hline tert-Butanol & 506.2 & 39.7 & 0.612 & AspenTech (1995) \\
\hline 2-Pentanol & 560.4 & 37.1 & 0.563 & AspenTech (1995) \\
\hline 1-Hexanol & 611.4 & 35.1 & 0.579 & AspenTech (1995) \\
\hline Allyl Alcohol & 545.0 & 56.2 & 0.569 & AspenTech (1995) \\
\hline 2-Butoxyethanol & 633.9 & 32.7 & 0.521 & AspenTech (1995) \\
\hline Cyclohexanol & 650.0 & 42.6 & 0.373 & AspenTech (1995) \\
\hline Acetic Acid & 592.0 & 57.9 & 0.467 & AspenTech (1995) \\
\hline Propionic Acid & 600.8 & 46.2 & 0.575 & AspenTech (1995) \\
\hline Acetone & 508.2 & 47.0 & 0.307 & AspenTech (1995) \\
\hline 2-Butanone & 535.5 & 41.5 & 0.323 & AspenTech (1995) \\
\hline Diethyl Ether & 466.7 & 36.4 & 0.281 & AspenTech (1995) \\
\hline Acetonitrile & 545.5 & 48.3 & 0.338 & AspenTech (1995) \\
\hline Ethanolamine & 678.2 & 71.2 & 0.447 & AspenTech (1995) \\
\hline Tetrahydrofuran & 540.2 & 51.9 & 0.225 & AspenTech (1995) \\
\hline
\end{tabular}


Table 7 (Continued)

\begin{tabular}{lllll} 
Acetaldehyde & 466.0 & 55.5 & 0.291 & AspenTech (1995) \\
Nitromethane & 588.2 & 63.1 & 0.348 & AspenTech (1995) \\
2-Methylpyridine & 621.0 & 43.8 & 0.278 & AspenTech (1995) \\
Ethyl Acetate & 523.3 & 38.8 & 0.366 & AspenTech (1995) \\
1,3-Butadiene & 425.2 & 42.8 & 0.190 & AspenTech (1995) \\
Methyl tert-butyl ether & 497.1 & 34.3 & 0.266 & AspenTech (1995) \\
trans-1,3-Pentadiene & 500.0 & 37.4 & 0.116 & AspenTech (1995) \\
Dimethyl Sulfide & 503.0 & 55.3 & 0.193 & AspenTech (1995) \\
Methyl Mercaptan & 470.0 & 72.3 & 0.158 & AspenTech (1995) \\
1-Butene & 420.0 & 40.4 & 0.191 & AspenTech (1995) \\
Dimethyl Disulfide & 606.0 & 53.6 & 0.265 & AspenTech (1995) \\
\hline
\end{tabular}


Table 8

Summary of results for the representation of bubble point pressures

\begin{tabular}{|c|c|c|c|c|c|c|c|c|c|}
\hline & CASE 1 & & CASE 2 & & CASE 3 & & CASE & & \\
\hline $\begin{array}{l}\text { TYPE OF } \\
\text { SYSTEMS }\end{array}$ & $\begin{array}{l}\text { RMSE } \\
\text { (Bar) }\end{array}$ & $\% \mathrm{AAD}$ & $\begin{array}{l}\text { RMSE } \\
\text { (Bar) }\end{array}$ & $\% \mathrm{AAD}$ & $\begin{array}{l}\text { RMSE } \\
\text { (Bar) }\end{array}$ & $\% \mathrm{AAD}$ & $\begin{array}{l}\text { RMSE } \\
\text { (Bar) }\end{array}$ & $\% \mathrm{AAD}$ & $\begin{array}{l}\text { NO } \\
\text { PTS }\end{array}$ \\
\hline $\begin{array}{l}\text { Low Pressure } \\
\text { Systems }\end{array}$ & 0.007 & 1.02 & & & 0.009 & 1.84 & 0.009 & 1.58 & 797 \\
\hline $\begin{array}{l}\text { Ethane + } \\
\text { Hydrocarbons }\end{array}$ & & & 0.43 & 1.17 & 0.42 & 0.88 & 0.19 & 0.51 & 266 \\
\hline $\begin{array}{l}\text { Carbon dioxide }+ \\
\text { Hydrocarbon }\end{array}$ & & & 0.78 & 0.96 & 0.36 & 0.78 & 0.28 & 0.58 & 264 \\
\hline $\begin{array}{l}\text { Nitrogen }+ \\
\text { Hydrocarbons }\end{array}$ & & & 2.24 & 1.91 & 2.28 & 1.57 & 2.08 & 1.54 & $243 *$ \\
\hline $\begin{array}{l}\text { Hydrogen }+ \\
\text { Hydrocarbons }\end{array}$ & & & 1.81 & 1.02 & 2.30 & 1.25 & 0.85 & 0.56 & $274 *$ \\
\hline
\end{tabular}

* - The number of points analyzed for Case 3 for these systems was slightly less than this number due to convergence problems. 
Table 9

Temperature dependence of the model parameters for the $(\theta / \phi)$ approach

\begin{tabular}{|c|c|c|c|c|c|c|c|c|}
\hline \multirow[b]{3}{*}{ SYSTEM } & \multirow[b]{3}{*}{$\begin{array}{l}\text { TEMP RANGE } \\
(\mathrm{K})\end{array}$} & \multicolumn{6}{|c|}{ DEVIATIONS IN PREDICTED BUBBLE POINT PRESSURES } & \multirow[b]{3}{*}{$\begin{array}{l}\text { NO } \\
\text { PTS }\end{array}$} \\
\hline & & \multicolumn{2}{|c|}{ CASE 4} & \multicolumn{2}{|c|}{ CASE 4a } & \multicolumn{2}{|c|}{ CASE 4b } & \\
\hline & & $\begin{array}{l}\text { RMSE } \\
\text { (Bar) }\end{array}$ & $\% \mathrm{AAD}$ & $\begin{array}{l}\text { RMSE } \\
\text { (Bar) }\end{array}$ & $\% \mathrm{AAD}$ & $\begin{array}{l}\text { RMSE } \\
\text { (Bar) }\end{array}$ & $\% \mathrm{AAD}$ & \\
\hline $\begin{array}{l}\text { Acetone + } \\
\text { Water }\end{array}$ & $308.2-373.2$ & 0.019 & 0.95 & 0.128 & 4.23 & 0.082 & 3.12 & 56 \\
\hline $\begin{array}{l}\text { Ethane }+ \\
\text { n-Octacosane }\end{array}$ & $348.2-423.2$ & 0.11 & 0.49 & 0.26 & 1.09 & 0.21 & 0.94 & 24 \\
\hline $\begin{array}{l}\text { Carbon dioxide }+ \\
\text { n-Decane }\end{array}$ & $310.9-510.9$ & 0.23 & 0.31 & 3.24 & 5.06 & 1.49 & 2.84 & 23 \\
\hline $\begin{array}{l}\text { Nitrogen }+ \\
\text { n-Hexadecane }\end{array}$ & $462.7-623.7$ & 0.55 & 0.37 & 2.26 & 1.66 & 2.82 & 1.56 & 22 \\
\hline $\begin{array}{l}\text { Hydrogen }+ \\
\text { Toluene }\end{array}$ & $461.9-542.2$ & 0.73 & 0.45 & 8.26 & 3.02 & 8.26 & 3.02 & 18 \\
\hline
\end{tabular}


Table 10

Comparison of results for the representation of bubble point pressures between the $(\theta / \phi)$ approach (Case 4b) and the conventional approaches (Case 1 or Case 2) for a system-by-system analysis

\begin{tabular}{|c|c|c|c|c|c|c|}
\hline \multirow[b]{2}{*}{ SYSTEM } & \multirow[b]{2}{*}{$\begin{array}{l}\text { TEMP RANGE } \\
(\mathrm{K})\end{array}$} & \multicolumn{2}{|c|}{ CASE $4 \mathrm{~b}(\theta / \phi)$} & \multicolumn{2}{|c|}{ CASE 1 OR 2} & \\
\hline & & $\begin{array}{l}\text { RMSE } \\
\text { (Bar) }\end{array}$ & $\% \mathrm{AAD}$ & $\begin{array}{l}\text { RMSE } \\
\text { (Bar) }\end{array}$ & $\%$ AAD & \\
\hline $\begin{array}{l}\text { Acetone + } \\
\text { Water }\end{array}$ & $308.2-373.2$ & 0.082 & 3.12 & 0.066 & 2.81 & $(\gamma / \phi)$ \\
\hline $\begin{array}{l}\text { Ethane + } \\
\text { n-Octacosane }\end{array}$ & $348.2-423.2$ & 0.21 & 0.94 & 1.04 & 3.54 & $(\phi / \phi)$ \\
\hline $\begin{array}{l}\text { Carbon dioxide }+ \\
\text { n-Decane }\end{array}$ & $310.9-510.9$ & 1.49 & 2.84 & 1.39 & 2.87 & $(\phi / \phi)$ \\
\hline $\begin{array}{l}\text { Nitrogen }+ \\
\text { n-Hexadecane }\end{array}$ & $462.7-623.7$ & 2.82 & 1.56 & 2.68 & 1.98 & $(\phi / \phi)$ \\
\hline $\begin{array}{l}\text { Hydrogen + } \\
\text { Toluene }\end{array}$ & $461.9-542.2$ & 8.26 & 3.02 & 8.97 & 4.87 & $(\phi / \phi)$ \\
\hline
\end{tabular}

